Columbia Law School

Scholarship Archive

1990

\title{
A Tale of Two Copyrights: Literary Property in Revolutionary France and America
}

Jane C. Ginsburg

Columbia Law School, jane.ginsburg@law.columbia.edu

Follow this and additional works at: https://scholarship.law.columbia.edu/faculty_scholarship

Part of the Comparative and Foreign Law Commons, and the Intellectual Property Law Commons

\section{Recommended Citation}

Jane C. Ginsburg, A Tale of Two Copyrights: Literary Property in Revolutionary France and America, 64 TUL. L. REV. 991 (1990).

Available at: https://scholarship.law.columbia.edu/faculty_scholarship/620

This Article is brought to you for free and open access by the Faculty Publications at Scholarship Archive. It has been accepted for inclusion in Faculty Scholarship by an authorized administrator of Scholarship Archive. For more information, please contact scholarshiparchive@law.columbia.edu. 


\title{
TULANE \\ LAW REVIEW
}

VoL. 64

MAY 1990

No. 5

\section{A TALE OF TWO COPYRIGHTS: LITERARY PROPERTY IN REVOLUTIONARY FRANCE AND AMERICA}

\author{
JANE C. GINSBURG*
}

\section{INTRODUCTION}

The French and U.S. copyright systems are well known as opposites. The product of the French Revolution, French copyright law is said to enshrine the author: exclusive rights flow from one's (preferred) status as a creator. ${ }^{1}$ For example, a lead-

* Associate Professor of Law, Columbia University. B.A. 1976, M.A. 1977, University of Chicago; J.D. 1980, Harvard University. Research for this Article was supported in part by the Columbia Law School Summer Research Grants program.

Thanks to my colleagues George Bermann, Richard Briffault, Henry P. Monaghan, and Peter Strauss, and to Professor John Merryman, Stanford Law School, for valuable comments on earlier drafts. Paola de Kock, Columbia Law School class of 1990, provided helpful research assistance. Special thanks to Professor Carla Hesse, University of California, Berkeley, Department of History.

This Article is based on a presentation made at the Library of Congress Symposium on Publishing and Readership in Revolutionary France and America, May 2, 1989.

Editor's note: It is with great pleasure that the Tulane Law Review publishes this piece on revolutionary copyright law in our May 1990 issue, at the time of the bicentennial of the United States first copyright law, which passed May 31, 1790.

1. The reports to the revolutionary parliaments of Le Chapelier, see Le Moniteur Universel, Jan. 15, 1791, reprinted in 7 REIMPRESSION DE L'ANCIEN MONITEUR 113, 11618 (1860) [hereinafter Report of Le Chapelier], and of Lakanal, see Le Moniteur Universel, July 21, 1793, reprinted in 17 REIMPRESSION DE L'ANCIEN MONITEUR, supra, at 169, 176 [hereinafter Report of Lakanal], usually furnish the leading evidence for these kinds of assertions. As discussed infra subpart III (A), these sources in fact prompt quite different conclusions. 
ing French copyright scholar states that one of the "fundamental ideas" of the revolutionary copyright laws is the principle that "an exclusive right is conferred on authors because their property is the most justified since it flows from their intellectual creation."2 By contrast, the U.S. Constitution's copyright clause, ${ }^{3}$ echoing the English Statute of Anne, ${ }^{4}$ makes the public's interest equal, if not superior, to the author's. This clause authorizes the establishment of exclusive rights of authors as a means to maximize production of and access to intellectual creations. ${ }^{5}$

Pursuing this comparison, one might observe that post-revolutionary French laws and theorists portray the existence of an intimate and almost sacred bond between authors and their works as the source of a strong literary and artistic property right. ${ }^{6}$ Thus, France's leading modern exponent of copyright theory, the late Henri Desbois, grandly proclaimed: "The author is protected as an author, in his status as a creator, because a bond unites him to the object of his creation. In the French tradition, Parliament has repudiated the utilitarian concept of protecting works of authorship in order to stimulate literary and artistic activity."7

By contrast, Anglo-American exponents of copyright law and policy often have viewed the author's right grudgingly. One of copyright's reluctant advocates, Lord Macaulay, labeled the

2. C. Colombet, Proprietét Littéraire et Artistique 8 (4th ed. 1988). All translations are mine, unless otherwise indicated.

3. U.S. ConsT. art. I, $\S 8$, cl. 8.

4. Statute of Anne, 1710, 8 Anne, ch. 19.

5. U.S. Const. art. I, $\S 8$, cl. 8. See generally Twentieth Century Music Corp. v. Aiken, 422 U.S. 151 (1975) (limits on the exclusive rights conferred by the Copyright Act of 1909); H.R. REP. No. 2222, 60th Cong., 2d Sess. (1909) (copyright policy will stimulate writing and invention); Monta, The Concept of "Copyright" Versus the "Droit d'Auteur," 32 S. CAL. L. REV. 177 (1959) (comparison of the Anglo-Saxon concept of copyright to the French concept).

6. See, e.g., Law of Mar. 11, 1957, No. 57-298, art. 1, 1957 Dalloz, Législation [D.L.] 102, Juris-Classeur Périodique [J.C.P.] No. 31, 22030; Portalis, Speech to Chamber of Peers (May 25, 1839), quoted in P. Recht, Le Drolt D'Auteur, UNE NOUvelle FORME DE PROPRIETÉ 49 (1969) (authors' rights in their works are not only "property by appropriation, but property by nature, by essence, by entirety, by the indivisibility of the object from the subject"); LAMARTINE, On Literary Property, Report to the Chamber of Deputies, 1841, in 8 OeuvRes CoMPlètes 394, 405 (Paris 1842) ("the very nature of this property, entirely personal, entirely moral, entirely united with the creator's thought").

7. H. Desbois, Le Droit D'Auteur en France 538 (3d ed. 1978) (describing 1957 French copyright law); see also Monta, supra note 5, at 178 (the text of the 1957 French law "sounds like the proclamation of the rights of men. These are obviously proclaimed to be natural rights independent of statute ...."). 
institution of copyright as "exceedingly bad," " but was willing to tolerate it as the means to promote the dissemination of socially useful works. 9 In this view, copyright should afford authors control no greater than strictly necessary to induce the author to perform his part of the social exchange. ${ }^{10}$

Conceptions of French copyright law as author-oriented and of Anglo-American copyright law as society-oriented carry certain corollaries. In general, one may anticipate that the more author-centered the system, the more protective the copyright regime will be. ${ }^{11}$ And the extent of this author-centrism will promote some interests over others. For example, some argue that the different foci of the systems account for the active protection of authors' noneconomic moral rights to receive attribution for and preserve the artistic integrity of their creations in France, and for the traditional paucity of such safeguards in the U.S. ${ }^{12}$ Similarly, the French perspective will encompass most comfortably works of discernible literary or artistic content, ${ }^{13}$ while the U.S. emphasis on social utility may explain its historically vigorous copyright coverage of works such as compilations conveying much information but little subjective authorial contribution, ${ }^{14}$ as well as its present receptivity to computer pro-

8. 1 C. Macaulay, Speech to House of Commons, Feb. 5, 1841, in The Works of Lord Macaulay: Speeches, Poems, \& Miscellaneous Writings 667 (1898).

9. Id. at 661-63.

10. For a modern American exposition of this view, see Breyer, The Uneasy Case for Copyright: A Study of Copyright in Books, Photocopies, and Computer Programs, 84 Harv. L. REV. 281, 350-51 (1970).

11. Cf. B. Kaplan, AN UNHURRIEd View OF Copyright 22-25 (1967) (as English authors perceived themselves more as original creators and less as imitative craftsmen, they began to assert more claims over their works; the scope of copyright protection accordingly expanded to cover not only exact copies, but partial copies and adaptations).

12. See, e.g., DaSilva, Droit Moral and the Amoral Copyright: A Comparison of Artists' Rights in France and the United States, 28 BuLL. COPYRIGHT SOC'Y 1, 51-56 (1980) (comparison of the French droit d'auteur to American copyright); Kwall, Copyright and the Moral Right: Is an American Marriage Possible?, 38 VAND. L. REv. 1, 9-16 (1985) (comparison of artistic protection in the U.S. and Europe); Note, An Author's Artistic Reputation Under the Copyright Act of 1976, 92 HARv. L. REv. 1490, 1492-96 (1979) (comparison of American copyright system to civil-law moral-rights system).

13. See, e.g., C. CARreau, Merite et Droit D'Autreur (1981); Desjeux, Logiciel, jeux vidéo, et droit d'auteur, EXPERTISES, Nov. 1984, at 277; cf. Dillenz, Qu'est-ce que le droit d'auteur et pourquoi l'appliquons-nous?, 59 IL DiRITTO DI AUTORE 349, 356 (1988) ("Who could truly assert, for example, that an advertising jingle, the instructions for a board game or a sample of wall paper belong to the 'most sacred and most personal of properties,' as Le Chapelier [proponent of the first revolutionary copyright law] did not hesitate to assert respecting works forming the subject matter of copyright?").

14. See, e.g., Ladd v. Oxnard, 75 F. 703, 731 (C.C.D. Mass. 1896) (protecting book of credit ratings and financial standings of stone dealers and manufacturers in U.S. and 
gram protection.

Another consequence of different copyright conceptions pertains to the role of formalities. Formalities are state-imposed conditions on the existence or exercise of copyright. If copyright is essentially a governmental incentive program, many formal prerequisites may accompany the grant. For example, requiring the author to affix a notice of copyright, or to register and deposit copies of the work with a government agency, before the right will be recognized or enforced is fully consistent with a public-benefit view of copyright. But these requirements clash with a characterization of copyright as springing from the creative act. If copyright is born with the work, then no further state action should be necessary to confer the right; the sole relevant act is the work's creation.

Despite these paradigms, the differences between the U.S. and French copyright systems are neither as extensive nor as venerable as typically described. ${ }^{15}$ In particular, despite the con-

Canada); Brightley v. Littleton, 37 F. 103, 104 (C.C.E.D. Pa. 1888) (sustaining copyright protection of blank forms); Emerson v. Davies, 8 F. Cas. 615, 619-20 (C.C.D. Mass. 1845) (No. 4436) (holding arithmetic book copyrightable).

15. The present differences between the systems are fast becoming muted. In 1985 France enacted computer program protection in terms reminiscent of the U.S. system, including the virtual exclusion of employee-creators from copyright ownership and the drastic curtailment of their moral rights. Law of July 3, 1985, arts. 45, 46, 1985 DallozSirey, Législation [D.S.L.] 356, J.C.P. No. 59, 57400. In 1987 France's highest civil-law court rejected copyright infringement challenges to the creation of certain data bases referencing and to some extent copying from pre-existing works. The court's and the First Advocate's rationales for curtailing the scope of the copyright in the referenced works recall analyses of U.S. courts under our "fair use" doctrine. Compare Judgment of Oct. 30, 1987, Cass. ass. plén., 135 Revue INTERNATIONALE DU DROIT D'AUTEUR [R.I.D.A.] 78 (1988) (unauthorized computerized index with summaries of, and excerpts from Le Monde) with New York Times Co. v. Roxbury Data Interface, Inc., 434 F. Supp. 217 (D.N.J. 1977) (unauthorized computerized subindex to the New York Times Index excused on fair use grounds). See generally Ginsburg, French Copyright Law: A Comparative Overview, $36 \mathrm{~J}$. COPYRIGHT Soc'y 269, 281-83 (1989) (discussing the two decisions).

On the United States side of the copyright rapprochement, in 1988 the U.S. modified its copyright law to join the Berne Convention, an international copyright treaty in which the standards reflect more French than Anglo-American copyright precepts. Thus, the U.S. now virtually has abandoned formalities as a condition of the existence or exercise of copyright and has asserted that it affords authors adequate protection of their moral rights. See generally Ginsburg \& Kernochan, One Hundred and Two Years Later: The U.S. Joins the Berne Convention, 13 ColUM. J.L. \& ARTS 1 (1988) (discussing changes in U.S. copyright law as a result of U.S. adherence to the Berne Convention). While the latter point remains debatable, U.S. courts have displayed an increased willingness to approach and favorably resolve questions about creators' interests in attribution and artistic integrity. See, e.g., Community for Creative Non-Violence v. Reid, 846 F.2d 1485 (D.C. Cir.), aff'd, 109 S. Ct. 2166 (1989) (raising issues of art object owner's compliance with artist's interests in attribution and integrity); Harper \& Row v. Nation Enters., 471 U.S. 539 (1985) 
ventional portrayal, the French revolutionary laws did not articulate or implement a conception of copyright substantially different from that of the regimes across the Channel and across the Atlantic. ${ }^{16}$ The French revolutionary sources themselves cast doubt upon the assumed author-centrism of the initial French copyright legislation. The speeches in the revolutionary assemblies, the texts of the laws, and the court decisions construing the laws, all indicate at least a strong instrumentalist undercurrent to the French decrees of 1791 and 1793. ${ }^{17}$ Similarly, while the law of U.S. letters predominantly reflects and implements utilitarian policies, U.S. law was not impervious to authors' claims of personal right. Indeed, some of the earliest U.S. state copyright laws set forth author-oriented rationales of which any modern Frenchman would be proud-and from which some revolutionary legislators might have drawn considerable inspiration. ${ }^{18}$

This Article examines the rhetoric and policies of the first French and U.S. copyright laws as well as their application in practice. Initially, I briefly review printing privileges under the ancien régime. Next, I examine the early Anglo-American copyright regime, with particular reference to the policies underlying the first U.S. copyright statute, and the works it covered. I then

(discussing author's integrity interests in right of first publication); Lamothe v. Atlantic Recording Corp., 847 F.2d 1403, 1407-08 (9th Cir. 1988) (recognizing co-author's right to claim attribution when all credit given to another co-author); Gilliam v. ABC, 538 F.2d 14, 24-25 (2d Cir. 1976) (discussing scriptwriters' right of integrity when television program is edited heavily by broadcaster). Further recognition of moral rights may yet emerge from our federal legislature. See, e.g., H.R. 2690, 101st Cong., 2d Sess. (1990) (rights of attribution and integrity for certain works of visual arts); REPORT OF THE REG. OF Copyrights, Technological Alterations to Motion Pictures (1989).

16. Cf. S. Ricketson, The Berne Convention for the Protection of LITERARY AND ARTISTIC WORKS: 1886-1996, at 5-6 \& n.11 (1987) (quoting J. KASE, COPYRIGHT THOUGHT IN CONTINENTAL EUROPE 8 (1971)):

It will be seen that both these [French revolutionary] laws placed authors' rights on a more elevated basis than the [English] Act of Anne had done. There was a conscious philosophical basis to the French laws that saw the rights protected as being embodied in natural law. Accordingly, the laws were simply according formal recognition to what was already inherent in the "very nature of things."

17. See generally C. Hesse, Res Publicata: The Printed Word in Paris 1789-1810 (dissertation presented to Princeton Univ. Oct. 1986) (discussed infra) (consideration of other primary sources supporting this conclusion).

18. See, e.g., Mass. Act of Mar. 17, 1783, reprinted in CoPyright ENACTMENTS of THE UNITED States, 1783-1906, Copyright OfFice Bulletin No. 3, at 11 (1906) [hereinafter COPYRIGHT OFF. BuLL. No. 3]. Pierre Recht suggests that a key phrase of this law's preamble was taken up by the reporter of the 1791 French law. P. RECHT, supra note 6 , at 26 . 
turn to the parliamentary speeches and texts of the French 1791 and 1793 decrees. Finally, I consider the French court decisions through 1814 construing the revolutionary copyright laws. This examination will demonstrate that the principles and goals underlying the revolutionary French copyright regime were far closer to their U.S. counterparts than most comparative law treatments (or most domestic French law discussions) generally acknowledge. The first framers of copyright laws, both in France and in the U.S., sought primarily to encourage the creation of and investment in the production of works furthering national social goals.

This study stops at the end of the Napoleonic era, substantially before the development of personalist doctrines, such as moral rights, by French copyright scholars and courts. These doctrines did provoke theoretical and practical divergences between the French and U.S. copyright regimes. ${ }^{19}$ But the later occurrences of a conceptual breach between the two copyright systems should not obscure the significance of their initial similarities. Recognizing this early congruence is important for several reasons.

First, in addition to the inherent interest the subject of comparative eighteenth-century copyright may hold, there is some value to setting the historical record straight. Second, historical accuracy may promote future legislative harmonization; now that increasing U.S. participation in international copyright agreements and policy-making bodies calls key features of the U.S. copyright system into discussion, one can properly argue that U.S. copyright has not always been different from that of its Continental partners. The comparison of systems shows that their distinctions are neither original nor immutable. A copyright regime's initial instrumentalist formulation does not preclude later reception of more personalist notions of protection. By the same token, a modern author-oriented copyright system's reference to its utilitarian past may assist its absorbtion of newer productions perhaps remote from the core of the beaux arts.

19. These doctrines emerged surprisingly late, at the end of the 19 th and the beginning of the 20 th centuries. See generally P. RECHT, supra note 6 . 


\section{COPYRIGHT Before 1791 (MODEls AVAILABLE to FRENCH REVOLUTIONARY LEGISLATORS)}

\section{A. Ancien Régime}

Since the late Renaissance the French Crown regulated the publishing industry; publishing monopolies were an offshoot of royal censorship. The author, or more often, the publisher or bookseller, applied for permission to publish the work and sought the privilege of holding the exclusive right of its publication. ${ }^{20}$ Under the edicts of $1777-78$, the Crown afforded printing privileges to both authors and printers. The author's privilege was perpetual, but once ceded to the publisher, or if initially acquired by the publisher, it lasted only during the life of the author. ${ }^{21}$ By the end of the ancien régime, much rhetoric proclaiming the sanctity and self-evidence of exclusive literary property rights had infiltrated the copyright debate, most of it propounded by publishers invoking authors' rights for the publishers' benefit, ${ }^{22}$ some of it by government advocates invoking authors' rights to curb publishers' assertions. ${ }^{23}$

The system of printing privileges was conditioned upon compliance with formalities: deposit of copies in national libraries, inclusion of the text of the privilege in each printed copy, and registration of copies with the publishers' guild. ${ }^{24}$ Remedies afforded by the privilege included injunctions and damages, as well as seizure, confiscation, and destruction of infringing copies. ${ }^{25}$ In addition to controlling the right to publish the work,

20. On regulation of publishing under the ancien régime, see generally M.-C. DocK, Etude sur le Droit D'Auteur (1963); H. FALK, Les Privilèges de Librairie Sous L'ANCIEN REGIME (1906 \& photo. reprint 1970); E. LABOULAYE \& G. GUIFFREY, LA Propriete litTéraire aU XVIIIE Siècle (Paris 1859); M.-F. MalaPert, Histoire ABregée de IA LEgislation sur la Propriéte LitTÉraire AVANT 1789 (1881); Birn, The Profits of Ideas: Priviléges en librairie in Eighteenth-Century France, 4 18THCENTURY STUD. 131 (1971); Henrion, Appoint à l'étude des privilèges de librairies aux $X V I e$ et XVIIe siècles, 6 R.I.D.A. 113 (1955).

21. Edict of Aug. 30, 1777, on Privileges arts. 4, 5, reprinted in E. LABOulaye \& G. Guiffrey, supra note 20, at 143, 145 [hereinafter Edict on Privileges].

22. See, e.g., the 1777 petition of the advocate Cochu on behalf of the Paris publishers, reprinted in E. LABOULAYE \& G. GUIFFREY, supra note 20, at 159-98. Cochu contended, "If there is one property which is sacred, self-evident, incontestable, it is doubtless that of authors in their works." Id. at 160. This and similar rhetoric would be echoed in the revolutionary assemblies. See infra text accompanying note 64 .

23. See Procés-Verbal Concernant la Librairie, excerpted in E. Laboulaye \& G. GUIFFREY, supra note 20, at 463-596.

24. Edict on Privileges, supra note 21, at 143-47.

25. See Edict of Aug. 30, 1777, on Infringement, reprinted in E. LABOULAYE \& G. GUIFFREY, supra note 20 , at $147-50$. 
the Crown also regulated rights of public performance of dramatic works by vesting in the Comédie Française the exclusive right to perform such works. ${ }^{26}$

\section{B. Anglo-American Copyright \\ 1. Statute of Anne (1710)}

England was the first nation to substitute a statutory rule of copyright law for a regime of royal favor. Known as the Statute of Anne, the first copyright statute was enacted in $1710 .{ }^{27}$ Its title and preamble enunciate the policy that became the essential rationale for both English and American copyright laws: copyright is an incentive to authors to create so that the public may have access to and be enriched by their works. ${ }^{28}$ The Statute of Anne is titled "An Act for the Encouragement of Learning, by vesting the Copies of printed Books in the Authors or Purchasers of such Copies." 29 Its preamble states that the Act is to discourage piracy and is "for the Encouragement of learned Men to compose and write useful Books." 30 The statute sought to accomplish these goals by conferring a reproduction right on authors for fourteen years, ${ }^{31}$ renewable for another fourteen, if the author was still living. ${ }^{32}$ The Act imposed the formalities of registration and deposit of copies as prerequisites to protection. ${ }^{33}$ Remedies included destruction of infringing copies and damages. ${ }^{34}$

\section{The Late Eighteenth-Century U.S. Copyright System}

The United States Constitution, drafted in 1787, and available in France in Philip Mazzei's French translation by at the latest 1790, authorizes a national copyright regime. In terms reminiscent of the Statute of Anne's incentive and access policy,

26. On the rights of dramatic authors and the Comédie Française under the ancien régime, see, e.g., J. Boncompain, Auteurs et CoMEdiens AU XVIIIE Sik̀cle (1976); J. BonNassies, les Auteurs Dramatiques et la Comédie Française auX XVIIE ET XVIIIE SIÈCLES (1874 \& photo. reprint 1970).

27. Statute of Anne, 1710, 8 Anne, ch. 19.

28. Id. at title and preamble.

29. Id. at title.

30. Id. at preamble.

31. Id.

32. Id. $\S \mathrm{I}$.

33. Id. $\S \mathrm{II}$.

34. Id. $\S \mathrm{V}$. On the Statute of Anne and its history, see, e.g., L. Patterson, Copyright in Historical Perspective 143-50 (1968); H. Ransom, The First COPYRIGHT STATUTE (1956). 
the Constitution declares "Congress shall have Power . . . to promote the Progress of Science and useful Arts, by securing for limited Times to Authors and Inventors the exclusive Right to their respective Writings and Discoveries."35 Later authorities have claimed that this phrasing subordinates the author's interests to the public benefit. For example, a report accompanying Congress 1909 general revision of the copyright law construes the Constitutional intent as follows:

Not primarily for the benefit of the author, but primarily for the benefit of the public, such rights are given. Not that any particular class of citizens, however worthy, may benefit, but because the policy is believed to be for the benefit of the great body of people, in that it will stimulate writing and invention to give some bonus to authors and inventors. ${ }^{36}$

Sources chronologically closer to the Constitution, however, treat the private and public interests more even-handedly. While records from the Constitutional Convention concerning the copyright clause are extremely sparse, a document dated August 18,1787, notes that the proposed legislative powers were submitted to the Committee of Detail: "To secure to literary authors their copy rights for a limited time. To encourage by proper premiums and provisions the advancement of useful knowledge and discoveries." 37 The referral to the Committee of Detail thus sets forth the authors' property interest ("their copy rights") and the public interest in advancement of knowledge as separate considerations of equal weight. Similarly, in The Federalist Papers, Madison endorsed the copyright clause, asserting, "The public good fully coincides in both cases [of patents and copyrights] with the claims of individuals." 38

Sources shortly predating the Constitution also indicate

35. U.S. CoNST. art. I, $\S 8$, cl. 8.

36. H.R. REP. No. 2222, supra note 3, quoted in A. LATMAN, R. GoRman \& J. GiNSBURG, COPYRIGHT FOR THE NinETIEs 14 (3d ed. 1989). For an exposition of the varying interpretations permitted by the constitutional text, see L. PATTERSON, supra note 34 , at $195-96$.

37. 1 Documents Illustrative of the Formation of The Union, H.R. Doc. No. 398, 69th Cong., 1st Sess. 130 (1927), quoted in Fenning, The Origin of the Patent and Copyright Clause of the Constitution, 17 GEo. L.J. 109, 112 (1929).

38. The Federalist No. 43, at 279 (J. Madison) (Mod. Lib. ed. 1941); see also Kauffmann, Exposing the Suspicious Foundations of Society's Primacy in Copyright Law: Five Accidents, 10 Colum.-VLA J.L. \& ARTS 381, 403-08 (1986) (challenging the dominance of a public benefit rationale underlying the constitutional copyright clause); Yen, Restoring the Natural Law: Copyright as Labor and Possession, 51 OHIo ST. L.J. (1990). 
American acknowledgement of authors' personal claims in addition to utilitarian motivations. Before enactment of the Constitution, protection of literary property was a matter for the states. In his essay Origin of the Copy-Right Laws in the United States, Noah Webster recounted the dire state of American education in 1782 and his resulting efforts to persuade state legislatures to protect publications. ${ }^{39}$ "[S]chool-books were scarce and hardly obtainable," Webster recalled. ${ }^{40}$ Having himself "compiled two small elementary books for teaching the English language,"41 he set off to New Jersey and Pennsylvania to seek copyright protection. The legislatures were not then in session, but Webster enlisted prominent local academic figures in his cause. A letter signed by professors at Princeton and the University of Pennsylvania sets the tone of the arguments in favor of copyright. After praising Webster's two works as "very proper for young persons in the country," the letter urges:

Every attempt of this nature undoubtedly merits the encouragement of the public; because it is by such attempts that systems of education are gradually perfected in every country, and the elements of knowledge rendered more easy to be acquired. Men of industry or of talents in any way, have a right to the property of their productions; and it encourages invention and improvement to secure it to them by certain laws, as has been practiced in European countries with advantage and success. And it is my opinion that it can be of no evil consequence to the state, and may be of benefit to it, to vest, by a law, the sole right of publishing and vending such works in the authors of them. ${ }^{42}$

While stressing the manifold benefits to public instruction flowing from protecting authors, Webster's fellow copyright lobbyists also invoked, on behalf of authors, the general Lockean principle that a property right arises out of one's labors. This mixed argumentation also emerges in the state copyright statutes that followed from both Webster's efforts and the next year's

39. N. WEBSTER, Origin of the Copy-Right Laws in the United States, in A Collection of Papers on Political, Literary and Moral Subjects 173 (N.Y. 1843 \& B. Franklin ed. photo. reprint 1968). The reader might conclude from Webster's account that he was virtually single-handedly responsible for the enactment of copyright laws, not only by the states before 1790 , but also by Congress in 1831 .

40. Id.

41. Id.

42. Id. at 173-74 (quoting letter of Samuel S. Smith (Sept. 27, 1782)); $c f$. Report of Lakanal, supra note 1 , at 176 (calling copyright "a right whose increase can neither harm republican equality, nor offend liberty"). 
Continental Congress resolution encouraging the thirteen states to pass copyright laws. ${ }^{43}$ For example, the preamble to the Massachusetts Act of March 17, 1783, first announced a public benefit rationale drawn from the English precedent, but then stated:

As the principal encouragement such persons can have to make great and beneficial exertions of this nature, must exist in the legal security of the fruits of their study and industry to themselves; and as such security is one of the natural rights of all men, there being no property more peculiarly a man's own than that which is procured by the labor of his mind. ${ }^{44}$

The first U.S. copyright statute, however, adopted a narrower view of authors' rights. The statute's title, "An Act for the encouragement of learning, by securing the copies of maps, charts and books, to the authors and proprietors of such copies, during the times therein mentioned,"45 suggests Congress intent to employ copyright as a means of furthering public education. The statute granted protection in these works to the author or his assigns for fourteen years, renewable for another fourteen, if

43. See "Resolution passed by the colonial Congress, Recommending the several States to secure to the Authors or Publishers of New Books the Copyright of such Books," May 2, 1783, reprinted in COPYRIGHT OfF. Bull. No. 3, supra note 18, at 11.

44. Mass. Act of Mar. 17, 1783, reprinted in Copyright OfF. Bull. No. 3, supra note 18, at 14; see also N.H. Act of Nov. 7, 1783, reprinted in COPYRIGHT OFF. BulL. No. 3 , supra note 18, at 18-19; R.I. Act of Dec. 1783, reprinted in COPYRIGHT OFF. BulL. No. 3 , supra note 18 , at $19-20$.

The organization of the Connecticut statute places the author's personal rights before the public's. It states:

Whereas it is perfectly agreeable to the principles of natural equity and justice, that every author should be secured in receiving the profits that may arise from the sale of his works, and such security may encourage men of learning and genius to publish their writings; which may do honor to their country, and service to mankind.

Conn. Act of Jan. 1783, reprinted in CopYright OfF. Bull. No. 3, supra note 18, at 11 . For wording that closely resembles that of the Connecticut statute, see N.C. Act of Nov. 19,1785 , reprinted in Copyright OFF. Bull. No. 3, supra note 18, at 25; Ga. Act of Feb. 3,1786 , reprinted in Copyright OFF. BuLl. No. 3, supra note 18, at 27; and N.Y. Act of Apr. 29, 1786, reprinted in COPYRIGHT OFF. BulL. No. 3, supra note 18, at 29. Another source concludes from this organization that "even though encouragement of learning was included as a reason for these four statutes, the primary purpose seemed to have been the enforcement of a pre-existing right-a property right in intellectual works." Crawford, Pre-Constitutional Copyright Statutes, 23 BulL. CopYRIGHT Soc'y 11, 15 (1975); see also L. PATTERSON, supra note 34, at 188 ("The dominant idea of copyright underlying the state statutes was the idea of copyright as an author's right."). But see $1 \mathrm{~J}$. TEBBEL, A History of Book PUblishing in the UNITEd STATES: The CReation of an INDUSTRY 1630-1865, at 139 (1972) (pointing out that the Connecticut statute "gave the Superior Court the right to withdraw copyright if the author did not 'furnish the Public with suffcient Editions' of a book").

45. Act of May 31, 1790, 1 Stat. 124. 
the author was still living. ${ }^{46}$ The Act imposed the formalities of registration and deposit of copies, together with affixation of a notice of copyright, as prerequisites to protection. ${ }^{47}$ Remedies included forfeiture of infringing copies and damages. ${ }^{48}$

\section{For What Kinds of Works Was Anglo-American Copyright Sought or Litigated?}

The works generating the subject matter of copyright deposits and claims reflect the general universe of late eighteenth-century American publications. Perhaps not suprisingly for a young republic, instructive, civics-oriented works dominate the publishing catalogues. For example, examination of the 5368 publications (including newspapers and pamplets) listed in the 1790-92 and 1798-99 volumes of Charles Evans's American Bibliography indicates that republican publishing habits corresponded to the "new republican ideology [that] defin[ed] the virtuous citizen as one who was broadly informed about political doctrine and public affairs."49 Evans's records for these years show 540 newspapers (157 newspapers for 1790-92, 383 for 1798-99), 441 titles in Political Science (207 for 1790-92, 234 for 1798-99), 302 titles in History (117 for 1790-92, 185 for 179899), 270 titles in Social Science (125 for 1790-92, 145 for 179899), and 61 Fourth of July orations for 1798-99. By contrast, the publication of novels appears fairly modest: 43 titles for 1790-92 and 119 for 1798-99..$^{\text {so }}$ This relative paucity of fiction also may

46. Id. $\S 1$.

47. Id. § 3. Formalities often proved fatal to U.S. authors' or publishers' claims. See, e.g., Wheaton v. Peters, 33 U.S. [8 Pet.] 591 (1834) (failure to comply with registration requirements); Clayton v. Stone, 5 F. Cas. 999 (C.C.S.D.N.Y. 1829) (No. 2872) (news bulletins held uncopyrightable because unamenable to compliance with formalities). For an argument that the onerous formalities established by the 1790 Federal Copyright Act "betrayed" U.S. authors, see Ringer, Copyright in Retrospect: Authors' Rights in Prospect, 14 COLUM. J.L. \& ARTS (forthcoming 1990).

48. Act of May 31, 1790, 1 Stat. 124, § 2. Neither the English nor the U.S. laws provided in the 18th century for a right of public performance.

49. Brown, Afterword: From Cohesion to Competition, in Printing AND Society IN EARLY AMERICA 300, 305 (1983).

50. The classifications are those of Evans. $8 \mathrm{C}$. EvaNS, AMERICAN BIBLIOGRAPHY 414, 416-20 (1941) (covering 1790-92); 12 id. at 389-91, 294-97 (1942) (covering 1798-99). For general bibliographical information concerning late 18th-century publishing in America, see, e.g., 9-11 id. (covering 1793-97); C. SHIPTON \& J. Mooney, NATIONAL INDEX OF AMERICAN IMPrints Through 1800: The SHORT-TITLE Evans (1969); Brigham, American Booksellers' Catalogues, 1734-1800, in EsSAYS HONORING LAWRENCE C. WROTH 31 (1951).

English authors wrote muich of the fiction; the titles published in the U.S. in 1790-92 included three editions of Defoe's Robinson Crusoe; two each of Fielding's Tom Jones and 
reflect republican values. Thomas Jefferson stated, "A great obstacle to good education is the inordinate passion prevalent for novels, and the time lost in that reading which should be instructively employed." 51

A review of the copyright records casts light on the smaller universe of works of actual or perceived economic value ${ }^{52}$ and allows comparison of government policy in enacting the copyright incentive to the kinds of works for which authors and publishers in fact accepted the government's offer. Copyright practice apparently met policy goals - copyright was sought for the socially useful, instructive works that Congress had intended to encourage.

Petitions to Congress before enactment of the first copyright statute sought exclusive privileges for works overwhelmingly instructional in character. For example, on May 12, 1789, Jedediah Morse petitioned for exclusive rights in The American Geography, or a View of the present Situation of the United States of America embellished and illustrated with two original maps, and on June 8, 1789, one Nicholas Pike, of Massachusetts, sought a privilege for $A$ new and complete System of Arithmetic. ${ }^{53}$ A recent comprehensive study of copyright deposit records covering the first ten years of the federal copyright system dis-

Joseph Andrews; three of Goldsmith's Vicar of Wakefield; and one each of Richardson's Pamela, Clarissa Harlow, and Sir Charles Grandison. See 8 C. Evans, supra, at 416-17. None of these could have been copyrighted in the U.S. because the first U.S. copyright statute (and all subsequent statutes until 1891, see 26 Stat. 1106) limited protection to U.S. works. U.S. publishers thus freely pirated English works, particularly novels. In the 19th century, Dickens and Trollope complained bitterly of such American practices. Out of creative solidarity and economic self-interest, American novelists also objected to the lack of protection for foreign works: pirate editions of English works undercut or depressed the price of their works. See Sandison, The Berne Convention and the Universal Copyright Convention: The American Experience, 11 Colum. J.L. \& ARTS 89, $92-93$ (citing works).

51. 15 T. JeFFERSON, THE WRITINGS OF ThOMAS JeFFERSON 166 (1903), quoted in FEDERAL COPYRIGHT RECORDS $1790-1800$ xxii (J. Gilreath ed. 1987).

52. Tebbel notes the "rather small" proportion of copyright registrations (556) to books published (13,000 titles recorded in Charles Evans's American Bibliography) during the first nine years of the federal statute. J. TeBsel, supra note 44 , at 142 . Tebbel concludes: "Obviously, the idea and opportunity of copyright were not grasped by everyone overnight." Id. See generally FEDERAL COPYRIGHT RECORDS 1790-1800, supra note 51.

53. See Proceedings in Congress During the Years 1789 and 1790, Relating to the First Patent and Copyright Laws, 22 J. PAT. OFF. Soc'y 243, 247-49 (1940) (reproducing the text of the petitions). Morse's work became the first to be deposited for federal copyright pursuant to the 1790 statute in the state of Massachusetts. Tebbel states that Morse's and Pike's works "may safely be said to be 'first' among [American] schoolbooks." J. TEBBEL, supra note 44, at 196. 
closes a preponderance of useful, instructional texts in deposits made pursuant to the first federal copyright statute. ${ }^{54}$ For example, of eighty copyright deposits recorded from 1790 through 1792 in Pennsylvania and Massachusetts (the states in which most works were published), thirty-four were of grammars, geographies, or similar instructional texts and another twentysix comprised informational works such as histories and almanacs. One scholar of publishing history attributes the dominance of textbooks in copyright registers in part to Noah Webster's efforts, ${ }^{55}$ and in part to national pride: "In the postRevolution textbook boom, the demand for primers, geographies and arithmetics, in both German and English, was high, as American books patriotically replaced the British texts that had been used before."56 The titles of several of the instructional works deposited for copyright convey their personally and patriotically uplifting aims. For example, Jedediah Morse titled another work, registered for federal copyright in Massachusetts on July 10, 1790, as follows: Geography made easy; being an Abridgement of the American Geography;-to which is added a geographical Account of the Eurpoean settlements in America \& of Europe, Asia \& Africa; illustrated with eight neat maps and [wood]cuts—calculated particularly for the use \& improvement of Schools in the United States; and Noah Webster titled one of his numerous educational endeavors, registered for federal copyright in Massachusetts on October 7, 1790, as follows: An American selection of lessons in reading and speaking. Calculated to improve the minds and refine the taste of youth. And also, to instruct them in the geography, history, and politics of the United States. ${ }^{57}$

U.S. copyright litigation, albeit sparse, seemingly also was

54. FEDERAL COPYRIGHT RECORDS 1790-1800, supra note 51; see also Goff, The First Decade of the Federal Act for Copyright, 1790-1800, in EsSAYS HoNORING LAWRENCE C. WROTH, supra note 50, at 101, 103 (pointing out preponderance of textbooks in early copyright registrations).

55. Of 69 titles on the English language published during 1790 to 1792,23 were by Webster. $8 \mathrm{C}$. EvaNS, supra note 50 , at 415 .

56. J. TEBBEL, supra note 44 , at 142 . Webster himself reaped the benefits both of his efforts to promote copyright and of nationalism. His spelling book "was a revolt against -. . everything the British grammars represented. Webster's spelling, usage and pronunciations were American. Its sales were phenomenal; only the Bible has ever surpassed it to this day [1972]." Id. at 198.

57. These works are catalogued as Nos. 265 and 267 in FEDERAL Copyright RECORDS 1790-1810, supra note 51, at 74. I have taken the title of Webster's work from entry No. 23050 in Evans's American Bibliography. See 8 C. EvaNs, supra note 50, at 103. 
reserved to quarrels over informational and similar works. A leading study has cited no copyright decisions before 1791 , and only two lower court decisions ${ }^{58}$ between that time and the U.S. Supreme Court's first copyright decision, Wheaton v. Peters, ${ }^{59}$ in $1834 .^{60}$ Both lower court cases concerned compliance with federal copyright formalities. Both also concerned works more of utility and of laborious compilation than of imagination-in one, a "federal calculator," and in the other, a Pharmacopoeia of the United States of America. Wheaton v. Peters involved a court reporter's claim of copyright in reports of U.S. Supreme Court decisions. ${ }^{61}$

\section{The French ENACTMENTS OF 1791 To 1793}

\section{A. Revolutionary Copyright Politics: Critical Discussion of the Legal Texts and Their Legislative History \\ While traditional comparisons of French to Anglo-Ameri-}

58. Ewer v. Coxe, 8 F. Cas. 917 (C.C.E.D. Pa. 1824) (No. 4584) and Nichols v. Ruggles, 3 Day 145 (Conn. 1808), cited in L. PATTERson, supra note 34, at 207 (1968).

59. 33 U.S. [8 Pet.] 591 (1834).

60. I have found two other federal copyright decisions predating Wheaton v. Peters. However, both postdate the French Revolution. See Clayton v. Stone, 5 F. Cas. 999 (C.C.S.D.N.Y. 1829) (No. 2872) (financial reports); Blunt v. Patten, 3 F. Cas. 763 (C.C.S.D.N.Y. 1828) (No. 1580) (navigation charts). Clayton v. Stone nonetheless is worth signaling for its restrictive interpretation of the term "book" in the 1790 copyright act. The court denied copyright protection to market reports published in daily newspapers on the ground that "books" imply some permanent contribution to knowledge; newspapers are too "ephemeral." 5 F. Cas. at 1003 . Moreover, stressed the court, the daily publication of newspapers makes them ill-adapted to compliance with the extensive statutory formalities. It followed that Congress could not have meant to include newspapers. Id.

61. Useful works also predominate in English copyright decisions predating the French revolutionary laws. See, e.g., Trusler v. Murray, 1 East 362 n.b., 102 Eng. Rep. 140 n.b. (K.B. 1789) (book of chronology); Sayre v. Moore, 1 East 361 n.b., 102 Eng. Rep. 139 n.b. (K.B. 1785) (sea charts); Carnan v. Bowles, 2 Bro. C.C. 80, 29 Eng. Rep. 45 (Ch. 1786) (road atlases); Gyles v. Wilcox, 2 Atk. 141, 26 Eng. Rep. 489, 3 Atk. 296, 26 Eng. Rep. 957, Barn. Ch. 368, 27 Eng. Rep. 682 (Ch. 1740) (law books). This condition continued in subsequent years. Augustine Birrell, the Victorian law professor and Member of Parliament, surveyed 19th-century English copyright cases, observing,

In reading the cases in the Reports for the last hundred years, you cannot overlook the literary insignificance of the contending volumes. The big authors and big books stand majestically on one side-the combatants are all small fry. The question of literary larceny is chiefly illustrated by disputes between bookmakers and rival proprietors of works of reference, sea charts, Patteson's "Roads," the antiquities of Magna Graecia, rival encyclopaedias, gazetteers, guide books, cookery books, law reports, post office and trade directories, illustrated catalogues of furniture, statistical returns, French and German dictionaries, Poole's farce, "Who's Who?" [and] Brewer's "Guide to Science."

A. BirRell, SeVen Lectures on the LAW AND History of Copyright IN Books 170-71 (1899), 
can copyright law assert that France rejected instrumentalist theories in favor of copyright as the just and fair prerogative of creators, research in primary sources prompts a different conclusion. The various legislative texts reveal a hesitating and uneven progress toward protection of authors' rights. Authors are not securely at the core of the new literary property regime; rather, the public plays a major role. The 1791 text predominantly is preoccupied with the recognition and enlargement of the public domain. The committee report in favor of the 1793 law emphasizes that protecting authors will not prove detrimental to society.

In the 1791 decree, the author's concerns do not occupy center stage. The report on the 1791 decree arose in a dispute between dramatists and the Comédie Française-the latter once the beneficiary of the exclusive right to produce theatrical works, the former once effectively indentured to the only approved theater. The decree's main goal was to proclaim the right of all citizens to open their own theaters and to produce plays, as the decree's first article states. Authors' rights are an adjunct to this freedom; just as any citizen may be a theatrical producer, so may any living author (or one dead for up to five years) be produced anywhere he wishes to be produced and only where he wishes to be produced. Plays by authors dead over five years are declared part of the public domain. The decree thus was designed to break the Comédie Française's monopoly on the works of Corneille, Molière, and Racine. ${ }^{62}$ Seen in its overall context, the decree's recognition of authors' rights principally was a means to terminate that monopoly.

It bears emphasis that the authors' rights are hardly ascendant. The reporter, Le Chapelier, is often quoted as a great exponent of author-oriented rationales for copyright. But almost invariably, the passage quoted is taken out of context. ${ }^{63}$

62. The Comédiens had indicated their willingness to relinquish monopoly rights in the works of living authors, but invoked the principle of nonretroactivity of new laws to insist on their continuing rights in long-deceased playwrights, such as those mentioned in the text (who, not incidentally, constituted the core of the repertory). See Report of Le Chapelier, supra note 1 , at 116.

63. See, e.g., M.-C. Dock, supra note 20, at 152; A. Françon, Cours DE Propriété littéraire, ArtistiQue et INdustrielle 15-16 (1980); E. Pouillet, Traite Thérique et Pratique de la Propriete Littéraire et Artistique $26 \mathrm{n} .1$ (3d ed. 1908).

Pouillet may have relied on several earlier treatise writers, whose incomplete quotations from Le Chapelier supply apparent evidence for an author-oriented concept of copyright. See, e.g., M. Gastambide, Historique et Théorie de la Proprieté deS 
Le Chapelier did declare that "the most sacred, the most legitimate, the most unassailable, and ... the most personal of all properties, is the work which is the fruit of a writer's thoughts." ${ }^{64}$ But he said it respecting unpublished works. Once disseminated, Le Chapelier went on to assert, the manuscript is "give[n] over to the public . . . by the nature of things, everything is finished for the author and the publisher when the public has in this way [through publication] acquired the work."65 According to Le Chapelier, the main principle is the public domain, to which authors' rights are an exception. He stressed that the new French law must put the principle and its exception in the right place; were the exception to replace the principle that "a published work is by its nature a public property," then "you will no longer have any basis for your law."66 Indeed, he criticized the English copyright law for setting up a strongly protected right rather than appreciating the principle of the public domain.

The text of the 1791 law followed Le Chapelier's organization of principles and exceptions: ${ }^{67}$ Article 1 pronounced the right of all citizens to erect theaters and to perform plays of all kinds; article 2 declared that works of authors who have been dead for over five years are public property; not until article 3 did the 1791 law set forth affirmative authors' rights by conditioning performances of the works of living authors upon their written consent. ${ }^{68}$

A subsequent decree on playwrights' copyright, handed

Auteurs $47 \mathrm{n} .1$ (Paris 1862) (quoting Le Chapelier); A. Nion, Droits Civils Des AUTEURS, ARTISTES ET INVENTEURS 39-40 (Paris 1846).

64. Report of Le Chapelier, supra note 1 , at 117.

65. Id. Le Chapelier's remark that "in the nature of things," publication marks the demise of authors' and publishers' rights thus rejects assertions of an inherent postpublication property right in literary works. Others would echo this position. See, e.g., Judgment of Jan. 20, 1818, Cass. crim., 52 Journal du Palais Recueil de la Jurisprudence [J. Pal.] 5 (pleading of defendant's advocate), quoted in 4 M. MERLIN, RECUEIL AlPHABETIQUe DE QUESTIONS DE DROIT 340-42 (4th ed. 1828). The defendant argued that neither natural law nor customary law accords to authors the exclusive right to reproduce their published works, but rather a "specific law grants this right, which derogates from the natural right acquired by all [to copy] as of the first publication of the work." Id. at 341 .

Eighteenth-century English copyright case law construing the Statute of Anne also distinguished between published and unpublished works. See Donaldson v. Beckett, reported in Millar v. Taylor, 4 Burr. 2303, 2408-17, 98 Eng. Rep. 201, 257-66 (1774).

66. Report of Le Chapelier, supra note 1 , at 117.

67. See id. at 118.

68. The sanction for unauthorized performances was confiscation of all revenues from the performances and their award to the authors. Article IV states the extent of the new 
down on August 30, 1792, also reflected Le Chapelier's weak embrace of authors' rights. The January 1791 decree had not satisfied the authors' demands. The public's right to establish theaters had come into conflict with the dramatists' right to authorize public performances; particularly in the provinces, theater owners were producing plays without paying the authors the full sums demanded. Beaumarchais petitioned the Assemblée Nationale for a law that would better assure authors' property interests. The resulting decree announced in the preamble that "the right to publish and the right to public performance, which incontestably belong to the authors of dramatic works, have not been sufficiently distinguished and protected by the law."69

However, the actual articles of the 1792 decree made dramatists' public performance rights even more vulnerable than under the 1791 decree. The 1792 decree subjected dramatist's rights to compliance with formalities. It imposed on the author the burden, at the time of the play's publication, to notify the public that the author had retained the public performance right. Articles 4 through 6 declared that the notice must be printed at the head of the text of the play and deposited with a notary. Unless these conditions were fulfilled, the dramatist's right would never vest. ${ }^{70}$ Moreover, article 8 of the decree declared that plays could be freely performed at the expiration of ten years following publication. In substituting a ten-year term for the 1791 decree's life plus five years, the 1792 measure may have shortened the duration of many playwrights' protection. ${ }^{71}$

law's retroactive effect. Article V confers a five-year post-mortem right on dramatists' heirs or grantees.

69. The text of the 1792 law, which is printed in the collected laws from June 1789 to August 1830, Bulletin ANNOTE DES LOIS, DECRETS ET ORDONNANCES (Paris 1834), does not include the preamble. It is set forth in Baudin, Rapport et projet de décret sur la propriété des auteurs dramatiques, présentés au nom du comité de l'instruction publique, in 1 Procès VerbauX du COMItE D'INstruction Publique de la Convention Nationale 349, 353 (M. Guillaume ed. 1891) [hereinafter Procès Verbaux].

70. The 1792 law thus harks back to the printing press règlement of 1723 governing publishing and bookselling: article 103 conditioned issuance of printing privileges on publication of the text of the privilege at the front or back of each copy; article 108 required deposit of copies in the royal libraries. See E. Laboulaye \& G. GiUfFrey, supra note 20, at 3, 5-7.

71. This 1792 decree, volubly resented by dramatists, was repealed by the Decree of Sept. 1, 1793. See 2 Procès VerbauX, supra note 69, at 353 (1894). Concerning the dramatists' efforts before the revolutionary legislature, see generally Fragments d'histoire de la protection littéraire, la lutte entre les auteurs dramatiques et les directeurs de théâtres sous l'Assemblée législative Française (1791-92), LE DroIT D'AUTEUR, Oct. 15, 1890̣, at 105-10. 
By 1793, however, the revolutionary legislators' copyright rhetoric had shifted away from Le Chapelier's public domain principle toward recognizing a property right in authors' works even after publication. But this shift did not markedly amend the prior reserved characterization of authors' rights, much less break with it. In the new formulation, authors would still not receive protection primarily for their own sake, but recognition of their rights would serve to promote the public welfare. Indeed, jurisdiction over elaboration of a copyright law had been transferred from the Committees on the Constitution and on Agriculture and Commerce to the Committee on Public Instruction. ${ }^{72}$ Enacting a copyright law formed part of a grander scheme of public education.

The report of Lakanal, ${ }^{73}$ on behalf of the Committee of Public Instruction, at first signaled a more favorable attitude towards authors' rights. This document (which, like Le Chapelier's report, is often quoted selectively) announced in its first sentence a property right in works of authorship. ${ }^{74}$ Lakanal also dubbed the proposed law the "Declaration of the Rights of Genius," thus stressing copyright's kinship to other great Rights of Man. ${ }^{75}$ But other aspects of the report reveal ambiguities. For example, Lakanal's pronouncement of an author's property right is guarded. Unlike ancien régime advocates of literary property, Lakanal did not assert that "the author is the master of his work, or no one in society is master of his property."76 Indeed, unlike Le Chapelier, Lakanal did not even affirm "the most sacred, ... the most personal of properties."77 Rather, he proclaimed that this right is "[o]f all rights the least subject to criticism, a right whose increase can neither harm republican equality, nor offend liberty."78 The rhetoric here displays a looking-over-the-shoulder quality inconsistent with a firm conviction of the centrality of authors' personal claims. ${ }^{79}$

72. See 1 Procès Verbaux, supra note 69, at iv. For a more detailed account of the shifts in committee responsibility in the revolutionary legislature over copyright legislation, see generally Hesse, Enlightenment Epistemology and the Laws of Authorship in Revolutionary France, 1777-1793, 30 REPRESENTATIONS 110 (1990).

73. Report of Lakanal, supra note 1, at 176.

74. Id.

75. See generally Declaration of the Rights of Man and of the Citizen (Fr. 1789).

76. Diderot, Sur la liberté de la presse 42, quoted in Birn, supra note 20, at 153. Diderot made the assertion at the behest of his publisher. Birn, supra note 20, at 152-53.

77. Report of Le Chapelier, supra note 1, at 117.

78. Report of Lakanal, supra note 1, at 176.

79. Interestingly, Pouillet's highly influential copyright treatise quotes this text quite 
Some nineteenth-century commentators buttress this conclusion. For example, in his 1858 study, Etudes Sur la propriété Littéraire en France et en Angleterre, Edouard Laboulaye voiced disappointment that Lakanal's report failed to affirm a true property right for authors. He charged that in Lakanal's report "one sees that nothing has changed in ideas, nor in legislation: the word property, it is true, has replaced that of privilege, but this property is still but a charitable grant from society." $\$$

The text of the 1793 decree also undercuts arguments that this law protects authors primarily because they are authors. Although in the version of the decree reported by Lakanal on July 21 there was no requirement of deposit as a prerequisite to suit, the final text incorporated the condition. As discussed earlier, ${ }^{81}$ conditioning the exercise of copyright upon compliance with formalities undercuts the notion of a right inherent in the author. ${ }^{82}$ Several early court decisions under the 1793 law held that deposit of copies, rather than simply meeting a procedural requirement, gave rise to the copyright. ${ }^{83}$ At the least, failure to deposit the work could result in an initially protected work's

selectively, removing the more insecure passages, those which claim that copyright will not harm the Republic. See E. PouILLET, supra note 63, at 14-15. Subsequently, many leading authors resorted to Pouillet's rendition, rather than to the original text. See, e.g., C. COLOMBET, supra note 2, at 7; A. FRANÇON, supra note 63, at 16. This confusion has perpetuated the view that the Revolution perceived copyright as "un veritable droit naturel." Id. (emphasis in original).

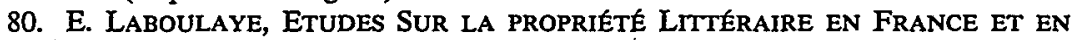
ANGLETERRE Xi (1858) (emphasis in original).

81. See supra text accompanying notes 14-15.

82. This observation is shared by R. CROUZEL, LE DEPôT LEGAL 31 (1936) (quoting Vaunois, Le dépôt légal des imprimés en France, 1916 LE DROIT D'AUTEUR 125, 125-27).

Others also criticized the 1793 deposit requirement, but on different grounds. A deposit requirement tied to initiation of suit in effect made deposit optional when no prospect of litigation existed. As a result, the 1793 law deprived the national library of a sure means to enrich its collections, thus "undermining . . . the progress of arts and sciences." Cholet de Jetphort, Projet d'organisation de l'imprimerie-librairie et des arts, états et professions qui y sont attachés ou qui en dépendent, adressé à Sa Majesté empereur et roi (1807), reprinted in H. LEMÂITRE, HISTOIRE DE DÉPÓT LEGAL, 3d pt., at 82 (1910). At the same time, the nondeposit bar to suit "conveys an indirect approval of the commerce in pirate editions, because, if one does not fulfill the deposit condition, one cannot pursue the infringer." Id.

83. Judgment of Oct. 23, 1806, Cass. crim., [1808] 2 Recueil Général des Lois et des Arrêts [Dev. \& Car.] 1.299; Judgment of Nov. 26, 1828, Cour royale, Paris, [1828] 9 Dev. \& Car. 2.159 .

The Judgment of Jan. 20, 1818, Cass. crim., 52 J. Pal. 5, considered compliance with formalities as giving rise to exclusive rights. The court stated that the plaintiffs "published the work in 1816 and fulfilled all the formalities prescribed for acquiring the exclusive right to sell." Id. at 12-13. The plaintiff's advocate made the same assumption when he contended that a French national first publishing abroad could nonetheless obtain 
falling into the public domain. ${ }^{84}$ These rulings suggest a judicial view that the act of authorship does not itself afford a basis for recognizing or maintaining protection of authors' rights.

The prominence of the public interest (and the public domain) in the 1793 law calls to mind Anglo-American notions of intellectual property. Indeed, an observer closer to the event noted the similarity. In 1838 Charles-Augustin Renouard, author of one of the first French copyright treatises, articulated two opposing philosophies of copyright. According to one, authors are the absolute owners of their work, both before and after publication. Their property right is, like all other property rights, transmissible, perpetual, and inviolable. According to the other system of copyright thought, authors are

workers and not property owners; if the laws ensure them exclusive exploitation of their works, it is by virtue of a positive grant of civil law and of a tacit contract which, at the moment of publication, intervenes between the public and the author. It is by the establishment of a privilege, created as a legitimate and fair compensation, that the full and free exploitation of a published work is forbidden to all persons composing the public. This is the system of the law of July $19,1793 \ldots{ }^{85}$

Renouard pursued his identification of the 1793 law with instrumentalist legislation, likening the 1793 law to French and English patent laws, both of which may be characterized as state grants in exchange for the ultimate enrichment of the public domain. ${ }^{86}$ Others agreed that the 1793 law did not afford

copyright protection in France by completing the formalities to which the privilege is subject. Id. at 8.

84. In Judgment of Mar. 1, 1834, Cass. crim., 1834 Dev. \& Car. 1.65, the Cour de cassation states that the 1793 law "guarantees literary property, upon condition of deposit of two copies with the Bibliothèque nationale" and refers to the "loss of that property right through failure of deposit." Id. at 75. As a result of this decision, the question whether deposit under the 1793 law created, perfected, or merely served to prove, the copyright became moot: the court held that subsequent enactments (in 1810,1814, and 1828) had substituted a different deposit requirement for that set forth in article 6 of the 1793 law. France required presuit deposit of copies of works of authorship until the beginning of the 20th century.

85. C.-A. Renouard, Des Droits des Auteurs Sur les Produits de Leur INTELLIGENCE 242 (1838).

86. Id.; see also Law of Dec. 31, 1790-Jan. 7, 1791, 6 Dalloz, Répertoire de Législation [D.R.L.] 528 n.1. The law's preamble mixes protective rationales, proclaiming,

Whereas any new idea whose demonstration or development can be useful to society belongs initially to him who conceived it, and that it would be an attack upon the rights of man in their essence to fail to deem an industrial discovery the property of its author; whereas the lack of a positive and authentic declaration of this truth may have contributed up until the present time to discourage French 
authors powerful guarantees of exclusive rights. Thus, parodying the Le Chapelier and Lakanal reports, Laboulaye lamented that under the 1793 law copyright had become "of all property rights the most humble and the least protected."

This examination of the legislative sources of the first French copyright laws reveals that these framers did not greet the concept of authors' property rights with the enthusiasm that later writers ascribed to them. Detailed treatment of the political, economic, social, and intellectual reasons behind this restrained embrace of copyright exceeds the scope of this Article. But two reasons for the framers' reluctance deserve at least brief notice. ${ }^{88}$ First, generally the most vociferous advocates for authors' rights were not authors, but their publishers, or, more specifically, the Paris Community of Book Sellers and Printers. ${ }^{89}$ Arguments for copyright therefore evoked images of guild selfinterest in a period of increasing anticorporatism. Not coincidentally the same legislator who presented the begrudging report for the 1791 copyright law, Le Chapelier, also sponsored the 1791 law dissolving guilds and corporations; the law's first arti-

industry, by causing the emigration of many distinguished inventors and by causing the loss to foreign countries of a great number of new inventions from which this empire should have drawn the first advantage.

Id. preamble (emphasis in original). Principles of public access and of the public domain predominate in the text of the law. See, e.g., id. art. 4 (inventor's obligation to declare the invention and deposit descriptions; the descriptions become publicly accessible upon issuance of the patent), art. 11 (all citizens may consult patent records and, in principle, descriptions), art. 15 (upon expiration of the patent, the discovery or invention belongs to society; all descriptions are rendered public, and anyone may use the invention), art. 16 (circumstances under which patent protection will be withdrawn, including false or incomplete descriptions, or two years of unjustified nonuse of the invention). For a recent discussion of the genesis and fate of the 1790-91 patent law, see Savignon, The French Revolution and Patents, INDUS. PROP., Nov. 1989, at 391-400.

In England, the Statute of Monopolies, 1623, 21 Jac. I, ch. 3 (1624), set forth the patent regime still in force at the time of the French Revolution and of Renouard's treatise. The Statute of Monopolies, primarily designed to eliminate or truncate grants of exclusive rights, recognized limited patent protection, but set inventors in second place to principles of free trade. Id. See generally B. Bugbee, The Genesis of American Patent and COPYRIGHT LAW 35-40 (1967) (development of English law concerning 'patents of invention).

87. E. LABOULAYE, supra note 80 , at xii.

88. For fuller discussions, see, e.g., Hesse, supra note 72; C. Hesse, supra note 17.

89. See generally Birn, supra note 20 (discussing the legal briefs and memoranda for representatives of the Paris publishers between 1710 and 1778. Many of these documents are reprinted in E. LABOULAYE \& G. GUIFFREX, supra note 20.).

Authors in England also enjoyed (or endured) the same tainted champions. See generally, e.g., B. BugBeE, supra note 86; L. PATTERSON, supra note 34; Rose, The Author as Proprietor: Donaldson v. Beckett and the Genealogy of Modern Authorship, 23 REPRESENTATIONS 51, 56 (1988). 
cle declared that "the abolition of all kinds of corporations of citizens of the same occupation and profession is one of the fundamental bases of the French Constitution."90

Second, and perhaps most importantly, a strong current of Enlightenment thought objected on instrumentalist grounds to any assertion of property rights in idea-bearing works: individual proprietary claims would retard the progress of knowledge. In 1776 a major exponent of this position, Condorcet, published a pamphlet on freedom of the press opposing not only censorship, but also copyright. ${ }^{91}$ Publishers' broadsides had analogized literary property to real property or chattels: an author owns his writings just as one who tills the field owns the fruits thereof. ${ }^{92}$ Condorcet challenged this analogy. He pointed out what is today called the "public goods" nature of copyright: a field belongs to only one person; by contrast, a literary work can belong to and be enjoyed by many simultaneously. Social intervention is needed to create and secure a property interest in such a work. If society is to intervene, the creation of a privilege must be necessary, useful, and just. To Condorcet, publishers' privileges, as they had developed by 1776, were none of these; rather, they concentrated power over books and thus power over ideas in a few hands. Condorcet therefore concluded that exclusive rights in literary works diminished, rather than enhanced, public debate. ${ }^{93}$

Condorcet's position was to change. The Revolution's suppression of privileges and the concomitant collapse of the publishers guild did not produce the outpouring of intellectual creations that might have been expected. In her illuminating study of the Paris publishing industry, Professor Carla Hesse observes that while abolition of the guild promoted the publication of pamphlets, broadsides, and works of similarly short length and timeliness, it also severely undermined the book trade. ${ }^{94}$ This phenomenon led revolutionary thinkers and legislators to perceive a crisis in ideas and letters. Unless some sys-

90. The Le Chapelier Law of June 14, 1791, translated in 7 UNIVERsity of Chicago Readings in Western Civilization: The Old Regime and the French REVOLUTION 248 (K. Baker ed. 1987).

91. M.J. CONDORCET, Fragments sur la liberté de la presse, in 11 OEUVRES DE CONDORCET 308-11 (M. Arago ed. Paris 1847).

92. See, e.g., Mémoir of Louis d'Héricourt, reprinted in E. LABoulaye \& G. GUIFFREY, supra note 20, at 21-40.

93. M.J. ConDORCET, supra note 91, at 311.

94. C. Hesse, supra note 17, at 165-67. 
tem of incentive and economic security were restored, book production, and hence the dissemination of the Enlightenment itself, might cease. Authors' exclusive rights became necessary to the perpetuation and further flowering of revolutionary ideals. Professor Hesse asserts that Condorcet as a result collaborated with the Abbé Sieyès on a proposed new press law (not passed), whose articles 14 through 21 stated: "The progress of the enlightenment, and thus of the public good, join themselves to ideas of distributive justice, to require that the law assure to authors the property right in their works."95 One may conclude that Condorcet, like Le Chapelier, perceived the public domain as the principle and copyright as an unhappy exception that practice had proved necessary and useful. Under this view, a just copyright law should be no more extensive than required to promote the public good. Thus, if as I argue, instrumentalist policies did indeed promote and infuse the revolutionary legislators' recognition of the exclusive right of reproduction, those policies may have derived from suspicion of proprietary rights in works of authorship, both as a matter of Enlightenment theory and antiguild practice.

I do not mean to suggest that French revolutionary legislators perceived copyright solely as a vehicle to foster the public welfare. Sympathy for authors' claims of moral entitlement to rights in their works surely influenced enactment of the 1791 and 1793 decrees as well. After all, the revolutionary copyright laws were drafted and enacted in a general climate formally recognizing natural rights, including the "sacred" right to property enunciated in the Declaration of the Rights of Man. ${ }^{96} \mathrm{My}$ point is that mixed motives underlay the French revolutionary copyright laws (as well as their U.S. counterparts) and that the parliamentary speeches and the texts of the laws themselves attest to a certain tension between authors' personal claims of right and the public interest in access to works of authorship. Thus, without denying the presence of a strong authors' rights current in the revolutionary laws, I would suggest that the revolutionary legislators generally resolved that public-versus-private tension by casting copyright primarily as an aid to the advancement of public instruction.

95. See 4 Histoire parlementaire de la Revolution Française 283 (Paris 1834), quoted in C. Hesse, supra note 17, at 164; see also Hesse, supra note 72.

96. Declaration of the Rights of Man, supra note 75, art. 17. 


\section{B. Revolutionary Copyright Practice: For What Kinds of Works Was French Copyright Litigated? What Kinds of Arguments Did the Advocates Press?}

If the motivations for enacting the first French and U.S. copyright laws were similar, what of the works they yielded? Comparison of the subject matter the two laws covered suggests that the two nations sought to promote dissemination of different kinds of works. The U.S. Constitution authorized Congress to create a copyright system to "promote the progress" of knowledge. Congress adopted a rather pragmatic view of the kinds of works that achieved that objective: the first copyright law protected maps, charts, and books-in that order. The great majority of works for which authors or publishers sought copyright protection under that first statute were highly useful productions.

The first French copyright law extended not merely to "writings of all kinds" but to "all productions of the beaux arts."97 Putting the two texts side by side, one might conclude that one law promoted Utility while the other sought Beauty. In fact, reports of French copyright infringement cases through 1814 indicate that, as in the U.S. and England, works of information or instruction were most often the subject matter of copyright litigation.

Moreover, even when the complaint of the French copyright owner concerned works of higher Arts and Letters, the arguments of the advocates would nonetheless sound familiar to an Anglo-American copyright litigant: incentive rationales loom large in the reasoning of lawyers and courts. ${ }^{98}$ The French copyright law may have protected a broader range of subject matter, but in both French and American cases, the subject matter advanced state interests. If the U.S. framers feared that art might distract hard-working citizens from useful achievements, ${ }^{99}$ the French revolutionaries saw art, or at least some kinds of

97. Law of July 19-24, 1793, arts. 1, 7, 38 D.R.L. 444.

98. See, e.g., Judgment of 29 therm. an 11, Cass. civ., [1791] 1 Dev. \& Car. 1.818 (reviewing the genesis of copyright law, defendant's advocate states "to advance the sciences it was necessary to encourage the savants, a very appropriate encouragement would be to assure them a private right over the printing and sales of their works"); Judgment of 12 vent. an 9, Trib. d'appel, Paris, [1791] 1 Dev. \& Car. 2.17, 2 J. Pal. 120 (discussed infra note 112).

99. See supra text accompanying note 51 . 
art, ${ }^{100}$ in the service of utility.

Art glorified the French Revolution and spread its ideals. A criminal copyright infringement affair from the Year 7 of the Republic illustrates the point. ${ }^{101}$ The work at issue was a play. Theatrical works were among those creations that the Revolution sought to encourage. ${ }^{102}$ The pleading stressed the utility of dramatic works in disseminating the Enlightenment and the Revolution. The prosecutor, complaining of inadequate enforcement of dramatists' rights in the provinces, declared:

Shall literary properties be less sacred in the eyes of the republican judge than other properties? It is to the wise men, to dramatic authors, to all literary authors that we principally owe the uncontested superiority of the French language over all the languages of Europe. It is they who render all nations tributaries to our arts, tastes, genius, glory; it is through them that the principles and rules of a wise and generous liberty penetrate beyond our borders and sphere of activity. ${ }^{103}$

I turn now to a more systematic review of copyright infringement actions and decisions under the law of 1793 (through 1814). This review examines both the subject matter and legal basis of the claims, and the nature of the arguments presented by the parties or sustained by the courts.

Of the thirty-seven controversies I have been able to gather (some controversies consist of multiple hearings and appeals), the subject matter of twenty-one concerns informational works. Another fifteen cases concern works of drama, music, art, poetry, or fiction. And the subject matter of one case is undisclosed. However, the initial subject-matter distinction between information and art is not entirely satisfactory: many of the

100. Jefferson and the French revolutionaries agreed to this extent: In France too, novels, it seems, were a disfavored form of literary expression. See infra note 103. (1954).

101. Judgment of 21 niv. an 7, Bureau criminel, Paris, excerpted in 2 R.I.D.A. 98

102. For example, daily reports in Le Moniteur Universel often included listings of plays in current performance in various theaters. The Feuille de correspondence du libraire, a biweekly listing of works published in France from 1791-92, lists many dramatic works, many of these on republican or revolutionary themes. See, e.g., No. 56, "Les citoyens français, ou le triomphe de la Révolution," prose drama in five acts by Pierre Vaque.

103. Judgment of 21 niv. an 7, 2 R.I.D.A. at 99 . Not all literary expressions, however, won revolutionary approbation. Drama might help spread the Enlightenment, but novels, apparently, were considered retrograde and useless. See, e.g., Lefebvre de Villebrune, Considérations sur le commerce de la librairie, Mar. 19, 1794, in 3 Prock̀s VerbauX, supra note 69, at 615 (1897), quoted in Hesse, The Dilemmas of Republican Publishing, 1793-1799, at 12-13 (to be published in the LIBR. CoNG. SYMP., Publishing AND READERSHIP IN REVOLUTIONARY FRANCE AND AMERICA (1991)). 
works of drama and poetry at issue purport not merely to entertain, but also to educate. ${ }^{104}$ Regarding the claims or defenses at issue, of these thirty-seven controversies, eleven decisions concern formal or procedural defects in the copyright or its enforcement. ${ }^{105}$

This subject-matter breakdown does not purport to reflect the overall relationship of published works of utility to published works of entertainment; ${ }^{106}$ rather, identification of the kinds of works that spawned litigation serves to indicate the kinds of works that generated sufficient popular demand to encourage piracy. Reference to the many decisions involving formal or procedural defects may elucidate the efficacy of the 1793 law in protecting authors' rights. Frequent foundering of authors' claims on these rocks suggests a copyright regime ill-adapted to vigorous enforcement of, and therefore perhaps not warmly receptive to, the author's monopoly.

Many decisions as reported forgo explaining the courts' rationales; they simply state the subject matter and the result. From the more detailed decisions, what approach to copyright emerges? While some decisions assert or presume that copyright inheres in the author, others, perhaps the majority, express or rely on more external justifications for protection. In the first group, a controversy from Year $2^{107}$ involved sales of unauthorized copies of memoirs. The plaintiff claimed the exclusive right of reproduction and distribution. Although some sales of the allegedly infringing copies took place after July 1793, the defendant contended that it acquired the copies before passage of the July 1793 copyright law. The defendant offered not to sell unauthorized copies in the future. Challenging the retroac-

104. See, e.g., Judgment of Dec. 2, 1808, Cass. crim., [1808] 2 Dev. \& Car. 1.609, 609 (works of Florian, including pastoral novels Estelle and Galatée; in his introduction to Estelle, the author claims to have "given a degree of usefulness to the pastoral novel"); Judgment of July 2, 1807, Cass. crim., [1808] 2 Dev. \& Car. 1.406, 406 (poem and critical essay, L'Imagination by Delille).

105. Bibliographic records for the revolutionary period are incomplete, but information identifying published books and pamphlets may be garnered from: Feuille de correspondence du libraire (1791-92); Journal Typographique et bibliographique (from 1797); see also A. BeUchot, Bibliographie de L'EMPIRE Français (Paris 1813).

106. The names and sources for the cases, as well as capsule descriptions, are set forth in the Appendix.

107. Judgment of 19 niv. an 2, Trib. ler arr., reported in 1 LES Tribunaux Civils de Paris Pendant la Revolution (1791-1800), Documents Inedits Recueillis Avant L'Incendie du Palais DE JUSTICE DE 1871 (A. Douarche ed. 1905) 657 [hereinafter Douarche]. This decision was affirmed by Judgment of 13 flor. an 2, 1 Douarche 657, 658 n.2, and by Judgment of 8 therm. an 2, Trib. 4e arr., 1 Douarche 794. 
tive application of that law, the defendant disclaimed liability for prior acts of copying and distribution.

The court ruled for the plaintiff, holding that "natural fairness, the first of all laws, sufficiently warned the printers and booksellers that it was not permitted to appropriate the productions of others, and that any time one harms the property of another, one is essentially obliged to compensate the harm suffered." The court's reasoning presumes that, even absent a law regulating booksellers, the author has a property right. Yet the court identified no formal source of this property right, ${ }^{108}$ but apparently perceived it as arising out of the creation of the work. Moreover, the court did not refer to any public benefit derived from protecting authors.

A later decision, Buffon c. Behmer, ${ }^{109}$ also recognized copyright protection for pre-1793 works, but not exclusively because of general fairness or an inherent property right. Rather, the Tribunal de cassation ruled that privileges granted under the 1777-78 edicts, if not expired under their own terms, remained in force. The reasons offered for the persistence of ancien régime printing privileges are of particular interest to this study.

Buffon's widow had charged a copyright infringement of Natural History, whose forty-year printing privilege granted under the ancien régime had not yet expired. The defendant responded that the August 4, 1789, decree generally abolishing ancien régime privileges had terminated the work's protection and cast it into the public domain, and that the August 20,1789, decree establishing freedom of the press entitled the defendant to publish whatever he wished. Buffon's widow appealed to the Tribunal de cassation, arguing that the August 4 decree did not apply to an author's rights under the prior edicts because these rights were not feudal and therefore were not targeted by the general abolition of privileges. Similarly, she contended, the August 20 decree simply recognized that "each man being the master of his own thoughts may write and publish them as he desires"; 110 the decree in no way authorized the appropriation of the works of others.

In holding that the 1777 decrees remained in force until

108. Cf. Judgment of May 25, 1793, Trib. 3e arr., 1 Douarche 471 (infringement of Paul et Virginie; validating seizure and condemning defendant to payment of the fine "prononcée par la loi"; court does not state what "law" is at issue).

109. Judgment of 29 therm. an 11, Cass. civ., [1791] 1 Dev. \& Car. 1.851.

110. Id. at 852 . 
prospectively superseded by the 1793 law, the court declared that

the decrees of August 1789, which abolished privileges and distinctions, and set the press free, have no relation to the property acquired by an author in his work, and which is simply the legitimate compensation for his work, and the price naturally owing for the enlightenment which he spreads throughout society. ${ }^{111}$

The court invoked both personal and external justifications for protection; it grounded the author's rights both in the act of creation and in the public benefits flowing from it. Thus, the court first endorsed the notion that authors have property rights in their works as the fruit of their labors, but then invoked the policy (fundamental to Anglo-American copyright) that copyright rewards authors because they contribute to the advancement of public instruction.

Other cases also contain reasoning consistent with the twin Anglo-American copyright goals of encouraging investment in, and the creation of, works of authorship to promote public education. ${ }^{112}$ One of these, the protracted affair of the Dictionary of the Académie française, ${ }^{113}$ merits attention both for the statements of the government official intervening on behalf of the plaintiffs, and for the Tribunal de cassation's holding. The plaintiffs were publishers who succeeded to rights granted by the revolutionary authorities to a prior publisher to prepare a fifth edition of the Dictionary. A new edition had been in preparation when the Académie française was suppressed by the decree of August 8, 1793. Plaintiff's' edition, incorporating the academi-

111. Id. at 853. But the 1793 law did not alter the terms, duration, or protection for works governed by the 1777 decree. See Judgment of 16 brum. an 14, Cass. crim., [1808] 2 Dev. \& Car. 1.177; Judgment of 27 prair. an 11, Cass. crim., [1791] 1 Dev. \& Car. 1.818 (both holding that works whose 1777 decree term of protection had expired were not entitled to new protection under the 1793 law).

112. See, e.g., Judgment of 29 therm. an 12, Cass. crim., [1791] 1 Dev. \& Car. 1.1023, 1023 (recognizing copyright in works by clerics because of the works' value to public education); Judgment of 12 vent. an 9, Trib. d'appel, Paris, [1791] 1 Dev. \& Car. 2.17, 18, 2 J. Pal. 120, 121 (author's interest in publicly delivered speech: plaintiff's advocate asserted that if speeches made in public were part of the public domain, then all authors would be compromised because publishers would rely on free public sources rather than paying authors for new written works); Judgment of 21 niv. an 7, Bureau criminel, Paris, No. 5380D.3, excerpted in 2 R.I.D.A. 98 (1954) (dramatic work discussed supra note 103 and accompanying text).

113. Judgment of 7 prair. an 11, Cass. crim., [1791] 1 Dev. \& Car. 1.806, 3 J. Pal. 293; Judgment of 28 flor. an. 12, Cass. crim., [1791] 1 Dev. \& Car. 1.971, 3 J. Pal. 747; Judgment of 6 flor. an 13, Trib. d'appel, [1808] 2 Dev. \& Car. 1.103, 4 J. Pal. 505. 
cians' notes for new articles, appeared in Year 6. Three years later, the defendants published a new edition of the Dictionary, based on the edition last published by the Académie and updated with the defendants' own new articles.

In the ensuing infringement action, the defendants disputed plaintiffs' copyright interest, arguing that with the abolition of the Académie française, the Dictionary became public property, available to all to republish or revise. The defendants also indicated that if anyone had a property interest in the Dictionary, under the terms of the 1793 law $^{\circ}$ granting copyright to "authors"114 and designating the "true owner" as the person to whom the infringer must pay damages, ${ }^{115}$ that person could only be the Dictionary's actual writers, not the State or the State's publisher-grantees. Countering this defense, the commissaire $d u$ gouvernement Merlin evoked a concept of authorship and of copyright that we would now consider far more American than French. Today the French copyright system generally proceeds from the principles that the "author" is the actual physical creator of the work and that the creator's status as an employee or commissioned party in no way affects authorship or initial title to copyright. ${ }^{116}$ (By contrast, U.S. copyright has embraced the doctrine of "works made for hire," and initial owner the employer or, in certain circumstances, the commissioning party. ${ }^{118}$ ) Construing the 1793 French law to favor plaintiffs' ownership claims in the Dictionary, Merlin declared that the plaintiffs were the lawful grantees of the State, and the State was the proper copyright owner of the Dictionary. He elaborated:

The word authors does not have, under the law, a meaning as restrictive as defendants have asserted. The word designates not only those who have themselves composed a literary work,

114. See Law of July 19-24, 1793, art. 1, 38 D.R.L. 444 (1857).

115. Id. art. 4 ("véritable propriétaire").

116. See Law of Mar. 11, 1957, No. 57-298, art. 1. But see id. art. 13 (initial title to copyright in collective works belongs to person or entity organizing the work's assemblage and publication).

117. 17 U.S.C. § 101 (1988).

118. Id.; see Varmer, Study No. 13, Works Made for Hire and on Commission, in 1 STUdies on COPYRIGHT (Arthur Fisher mem. ed. 1963) (discussing 1909 Copyright Act and its judicial interpretation). But see id. at 721 (asserting that older cases vested initial copyright ownership, but not authorship status, in employer, citing Colliery Eng'r Co. v. United Correspondence Schools Co., 94 F. 152 (C.C.S.D.N.Y. 1899); Atwill v. Ferrett, 2 F. Cas. 195 (C.C.S.D.N.Y. 1846) (No. 640) (both vesting initial copyright ownership in employer or commissioning party)). 
but also those who have had it written by others, and who have had the work done at their expense. ... The rights that belong to the nation belong to it because it is the nation which itself instituted and paid the Académie française to compose this dictionary. ${ }^{119}$

The court upheld the plaintiffs' assertion of a copyright interest on the ground that the plaintiffs were the "true owner[s]" envisioned by the 1793 text:

In the letter, as well as the spirit of the law, the true owner to compensate for the infringement is the owner of the original publication, that is, the publisher, because under the tort of infringement only the publisher's interests are harmed by the infringement of the original edition. ${ }^{120}$

The court's reasoning diverges from a view of copyright as the proper reward for the author's creativity. Rather, the real party of interest was the person who financed and disseminated the work. The court may have perceived the publisher as the proper claimant of a right to compensation for its investment. But contemporary publishers did not directly claim such rights for themselves; they claimed to be the contractual beneficiaries of the authors' rights. ${ }^{121}$ The court appears to identify the publisher as the true owner because, by funding and distributing the work of authorship, the publisher is the vital link between the work and its public. ${ }^{122}$

Other decisions casting doubt on the supposed author-centrism of French revolutionary copyright turn on the plaintiff's compliance with formalities and the place of the work's first publication. In these cases, the emphasis on territorial factors ${ }^{123}$

119. Judgment of 7 prair. an 11, Cass. crim., [1791] 1 Dev. \& Car. 1.806, 3 J. Pal. 293, 297-98 (emphasis in original).

120. $3 \mathrm{~J}$. Pal. at 300 . In a later stage of the proceeding, the court rejected defendants' assertion that their edition did not infringe plaintiffs' because they had not copied plaintiffs' new material, but had added their own new articles. Citing both the 1793 law and the 1777 decree, the court held that copying and revising the underlying work was also infringement. Judgment of 28 flor. an 12, Cass. crim., [1791] 1 Dev. \& Car. 1.971, 3 J. Pal. 747. A final, procedural, aspect of the case was decided in Judgment of 6 flor. an 13, Trib. d'appel, [1808] 2 Dev. \& Car. 1.103, 4 J. Pal. 505.

121. See supra note 89 and accompanying text.

122. Cf. Note, Joint Authorship of Commissioned Works, 89 ColUM. L. REv. 867, 877 (1989) (arguing that certain hiring parties should enjoy authorship status under U.S. copyright law: "Recognizing deserving commissioners as joint authors is further conducive to the constitutional purpose of benefiting the public insofar as it facilitates the exploitation and distribution of creative works.")

123. See, e.g., Judgment of Mar. 23, 1810, Cass. Crim., [1809-11] 3 Dev. \& Car. 
or on fulfillment of state-imposed conditions ${ }^{124}$ suggests that the magistrates did not consistently perceive copyright as a right inherent in the author. For example, the role of the deposit of copies with the Bibliotheque nationale as constitutive or merely declarative of the author's rights remained ambiguous throughout the revolutionary and Napoleonic periods. ${ }^{125}$ If deposit constitutes, rather than simply proves, copyright, then the right cannot arise out of the mere act of authorship.

Similarly, judicial pronouncements respecting the territoriality of authors' rights undermine the traditional characterization of revolutionary copyright as a confirmation of rights inherent in the author. The key element in these cases is not authorship, but completion of acts within French territory. Several controversies involved works copied in territories that subsequently became annexed to France, or works that were initially published and sold abroad. In the annexation cases, the courts generally held that once the territory became part of France, defendant publisher was bound by French law, even concerning copies made before annexation. ${ }^{126}$ On the other hand, if the work was first published abroad (in a territory not annexed to France), and a third party published and deposited copies in France before the author, the author had no rights in France, even if the author became a French citizen. ${ }^{127}$ Because acts within the French territory were dispositive, even a stranger to the work could acquire the rights of an author in France if he became the first to publish there. Not until the middle of the nineteenth century did France extend copyright to foreign authors based on their authorship status, rather than on the basis of first local publication. ${ }^{128}$

1.167, 167; Judgment of 29 frim. an 14, Cass. crim., [1808] 2 Dev. \& Car. 1.197, 197; Judgment of 17 niv. an 13, Cass. crim., [1808] 2 Dev. \& Car. 1.53, 54.

124. See, e.g., Judgment of Nov. 17, 1814, Cass. crim., [1812-14] 4 Dev. \& Car. 1.630, 631; Judgment of July 2, 1807, Cass. crim., [1808] 2 Dev. \& Car. 1.406, 406; Judgment of Mar. 23, 1810, 3 Dev. \& Car. at 167; Judgment of 8 fruct. an 11, Trib. d'appel, Seine, [1791] 1 Dev. \& Car. 2.158, 159.

125. See supra notes $83-84$ (discussion of decisions).

126. See Judgment of 29 frim. an 14, Cass. crim., [1808] 2 Dev. \& Car. 1.197, 197; Judgment of 29 therm. an 11, Cass. civ., [1791] 1 Dev. \& Car. 1.851, 852.

127. See Judgment of 17 niv. an 13, Cass. crim., [1808] 2 Dev. \& Car. 1.53; Judgment of Mar. 23, 1810, 3 Dev. \& Car. at 167; see also Judgment of Jan. 30, 1818, Cass. crim., 52 J. Pal. 5, 12-13 (work first published in England by French émigré held protected under French law when author's French publisher published and deposited copies in France before any competing French publisher's publication).

128. Decree of Mar. 28-30, 1852, cited in S. Rickerson, supra note 16, at 20-21. France was the first country to extend reproduction rights to foreign authors without 


\section{CONCLUSION}

This examination of the French revolutionary sources of copyright law reveals that revolutionary legislators, courts, and advocates perceived literary property primarily as a means to advance public instruction. Contemporary authorities certainly also recognized authors' claims of personal rights arising out of their creations, but the characteristic modern portrayal of French revolutionary copyright as an unambiguous espousal of an author-centric view of copyright ${ }^{129}$ requires substantial amendment. Similarly, this study has shown that familiar conceptions of early U.S. copyright also warrant reconsideration. If U.S. copyright's exponents sought to promote the progress of knowledge, they also recognized that the author's labors are due their own reward. The revolutionary French and American systems shared much not only in theory, but also in practice. In both systems, formalities encumbered, and sometimes defeated, the acquisition or exercise of copyright protection. And both systems primarily protected works useful to advancing public instruction. An appreciation of the similarities between the initial French and U.S. literary property regimes may hold significance for modern copyright systems because it undermines historical assertions of the inherent and original incompatibility of the French and Anglo-American approaches to copyright. In fact, modern advocates of international copyright harmonization may draw upon a rich tradition of copyright congruity to formulate mutually acceptable principles for the protection of works of authorship.

reference to reciprocity. On the other hand, France required that the work be protected in its country of origin. See H. Batiffol \& P. LAgarde, 2 Droit International Prive, $\S 530$, at 200-01 \& n.7 (7th ed. 1983). Moreover, protection did not initially extend to public performances of foreign works in France. See Judgment of Dec. 14, 1857, Cass. req., 1858 Recueil Dalloz Périodique et critique 1.161, 164 (concerning Verdi operas).

129. See, e.g., works cited supra notes $2,5,16$ \& 79 . 
APPENDIX

DECISIONS ON AUTHORS' RIGHTS, OR INTERPRETING THE 1793 LAW (FROM 1793 THROUGH 1814)

\section{SOURCES:}

A. Reporters

1. L.-M. Devilleneuve \& A.-A. Carette, Recueil Général des lois et des arrêts [Dev. \& Car.], 1er sér., 1791-1830 (Paris, from 1840).

2. Dennevers, Journal des Audiences de la Cour de Cassation [Den.] (Paris, from 1808).

3. Les Tribunaux civils de Paris pendant la Révolution (17911800), Documents inédits recueillis avant l'incendie du Palais de Justice de 1871 (A. Douarche ed. 1905) [Douarche].

4. Ledru-Rollin, Journal du Palais Recueil de la Jurisprudence Française [J. Pal.] (1838).

\section{B. Digests:}

1. M. Merlin, Repertoire UNiversel et RaisonNe DE JURISPRUDENCE (5th ed. Brussels 1826) (headings: Contrefaçon, Propriété Littéraire).

2. M. Merlin, Recueil de Questions de DRort (4th ed. 1828) (headings: Contrefaçon, Propriété Littéraire).

\section{Periodical:}

REVUE INTERNATIONALE DU DROIT D'AUTEUR [R.I.D.A.], Jan. 1954, at 98-99.

\section{CASES:}

A. Post-1789 Copyright Cases Arising and Judged Before the 1793 Copyright Law

1. Judgment of Feb. 27, 1793, Trib. 6e arr., 1 Douarche 390 (following default judgment of Feb. 23, 1792), Bernardin de St.Pierre c. Prieur (alleged infringement-contrefaçon-of novels Paul et Virginie and La Chaumière Indienne; seizure lifted for lack of proof that defendant's copies were unauthorized; court did not assert that no remedy is available because no law reprimanded unauthorized copying and selling; the court did not refer to any legal text). This decision was reversed by Judgment of May 25, 1793, Trib. 3e arr., 1 Douarche 471 (The court declared the 
seizure good and condemned defendant to payment of the fine "prononcée par la loi," but did not say which law).

2. Judgment of Mar. 15, 1793, Trib. 5e arr., 1 Douarche 401, Chaignieau c. Lachave (usurpation of title and format of newspaper Le Journal du Soir; defendant imitated plaintiff's journal "down to the smallest details" of typeface and layout; defendant ordered to cease "falsely indicating the name" of plaintiff publishers).

\section{B. Copyright Cases Arising Before 1793 Law, But Judged Subsequently}

3. Judgment of 19 niv. an 2, Trib. 1er arr., 1 Douarche 657, Latude c. Bossange (infringing copies and sales of plaintiff's memoirs), aff' $d$, Judgment of 13 flor. an 2, Trib. 1er arr., id. at $658 \mathrm{n.2}$, and by Judgment of 8 therm. an 2, Trib. 4e arr., 1 Douarche 794 [discussed in text].

\section{Cases Both Arising and Judged Under the July 1793 Law}

4. Judgment of 19 pluv. an 4, Trib. civ., Seine, 3e sec., 2 Douarche 282, Bernardin de St.-Pierre c. Siret (infringement of Etudes de la nature); Judgment of 25 therm. an 4, Trib. civ., Seine, 2 Douarche 329 (appointment of expert for calculation of damages).

5. Judgment of 5 flor. an 4, Trib. civ., Seine, 3e sec., 2 Douarche 305, Fabre d'Eglantine c. Barba (infringement of play L'Intrigue épistolaire), aff'd, Judgment of 22 prair. an 4, Trib. civ., Seine, 3e sec., 2 Douarche 318; Judgment of 24 therm. an 5, Trib. civ., Seine, 3e sec., 2 Douarche 426; Judgment of 5 vent. an 6, Trib. civ., Seine, 2 Douarche 471.

6. Judgment of 14 fruct. an 5, Trib. civ., Seine, 3e sec, 2 Douarche 435, LaHarpe c. Barba (infringement of Du fanatisme dans le langage révolutionnaire). Plaintiff-publisher included a notice that his edition was "Avec Autorisation de l'Auteur" and a further statement that "[w]e have just learned that someone is engaged in counterfeiting this work: the publisher must be ignorant of the respect due to property. We leave to the enlightened Public the task of avenging on our behalf this violation of all principles ...."."

7. Judgment of 29 therm. an 6, Trib. civ., Seine, 3e sec., 2 Douarche 550, Rousseau c. Parmentier (ordering defendant to acknowledge Rousseau as the sole author of the Morale de l'empereur Marc Aurèle). 
8. Judgment of 13 frim. an 7, Trib. civ., Seine, 3e sec., 2 Douarche 582, Merlin c. Dufart (seizure and damages awarded in favor of publisher of Works of Marmontel).

9. Judgment of 23 frim. an 7, Trib. civ., Seine, 3e sec., 2 Douarche 585, Merlin c. Garnery (confiscation and damages in favor of publisher of Marmontel's Moral Tales).

10. Judgment of 21 niv. an 7, Bureau criminel, Paris, excerpted in 2 R.I.D.A. 98 (1954) (drama) [discussed in text].

11. Judgment of 7 pluv. an 7, Trib. civ., Seine, 3e sec., 2 Douarche 606, Jeudy-Dugour c. Déterville (seizure and damages in favor of publisher of Elementary Dictionary of Botany).

12. Judgment of 13 pluv. an 8, Trib. civ., Seine, 3e sec., 2 Douarche 727, Gratiot c. Chénier (rejecting Chénier's demand to confiscate unauthorized copies of speech he publicly delivered in the Champ-de-Mars; trial court determined that the speech was dedicated to the public and that the 1793 law was inapplicable), rev'd, Judgment of 12 vent. an 9, Trib. d'appel, Paris, [1791] 1 Dev. \& Car. 2.17 (noted infra at App. 12.1).

12.1 Judgment of 12 vent. an 9, Trib. d'appel, Paris, [1791] 1 Dev. \& Car. 2.17, Chénier c. Gratiot (protectability of political speeches delivered in public; plaintiff's advocate suggested that if public speeches were freely copiable, their creation would be discouraged).

13. Judgment of 7 vent. an 7, Trib. civ., Seine, 1re sec., 2 Douarche 618, Mérard-St.-Juste c. Maradan (publisher of the Mémoires de la Baronne Dalvigny — a work apparently "sought after for its allusions licencieuses," id. at 618 n.1-violated agreement to turn over profits from sales, and published an unauthorized second edition. The author had reserved ownership rights in the work despite submitting the manuscript to a publisher).

14. Cass. 4 fructidor VII (affirming arrêté du directoire 27 messidor VII, annulling judgment of jury director of Lyon 8 flor. VII), referred to in account of pleadings in Den. An XII p. 1 (the work at issue was Rozier's Cours d'Agriculture).

15. Judgment of 27 vent. an 9, Cass. crim., [1791] 1 Dev. \& Car. 1.439, 440, Ministère Public c. Louvet (power of state to bring criminal infringement action for infringement of novels, including an apparently licentious work by the Chevalier de Faublas and a work titled Emilie de Varmont); see also case noted infra at App. 15.1.

15.1 Judgment of 9 mess. an 13, Cass. crim., [1808] 2 Dev. \& 
Car. 1.130, Bidault c. Louvet (novels, Chevalier de Faublas and Emilie de Varmont; issue concerned legality of seizure).

16. Judgment of 16 vent. an 10, Cass. crim., [1791] 1 Dev. \& Car. 1.606, Jean c. Auber (subject matter: prints of revolutionary battle scenes; bookseller held infringer, not mere reseller, of illicit reproductions).

17. Judgment of 7 prair. an 11, Cass. crim., [1791] 1 Dev. \& Car. 1.806, Bossange c. Moutardier (the case of the Dictionnaire de l'Académie) [discussed in text].

17.1 Judgment of 28 flor. an 12, Cass. crim., [1791] 1 Dev. \& Car. 1.971, Bossange c. Moutardier (Dictionnaire de l'Académie) [discussed in text].

17.2 Judgment of 6 flor. an 13, Cass. crim., [1808] 2 Dev. \& Car. 1.103, Moutardier c. Bossange (Dictionnaire de l'Académie) [discussed in text].

18. Judgment of 12 prair. an 11, Cass. crim., [1791] 1 Dev. \& Car. 1.810, 810, Buffon c. Behemer (criminal jurisdiction in affair regarding Natural History, a pre-1793 work whose 40-year privilege (if still valid) had not yet expired; court sustained prosecutor's arguments that under 1777 and 1778 edicts, copyright infringement was a crime, and that these laws "were not at all abrogated, but simply modified by [that] of 1793"); see also case noted infra at App. 18.1.

18.1 Judgment of 29 therm. an 11, Cass. crim., [1791] 1 Dev. \& Car. 1.851, Buffon c. Behemer (work on natural history; question of applicable law) [discussed in text].

19. Judgment of 27 prair. an 11, Cass. crim., [1791] 1 Dev. \& Car. 1.818, Ducaurroy et Le Normand c. Bruisset (subject matter: work of religious devotion; if term of protection expired during duration afforded under ancien régime dispositions, the grantee could not now invoke a new term under 1793 law's duration).

20. Judgment of 8 fruct. an 11, Trib. crim., Seine, 3 J. Pal. 431, Lassaux c. Bertrandet, concerned Masson's Letters from a Frenchman to a German; unauthorized copies of the work were made before the authorized publisher effected deposit with the Bibliothèque nationale. Suit commenced following deposit. Question: Does deposit give rise to, or at least perfect, the copyright, so that no predeposit copying is actionable, or does the deposit simply enable the rights holder to initite court action? The first-level court held the former and dismissed the complaint. 
On appeal, plaintiff-publisher argued that the author is not required to accomplish some act to create his rights, but only to relinquish them. Plaintiff contended that the author's rights do not "degenerate into public property" without either the author's written consent or an express legal disposition. According to plaintiff, the 1793 law's deposit requirement was not sufficiently specific; it did not affect the property rights in existence, it only conditioned the ability to bring a court action to enforce the property right.

Defendant-bookseller argued that full rights do not attach until the author has complied with the deposit because the deposit requirement "is founded in the interests of all, upon the need to promote the sciences and arts." Id. at 432. The court reversed, without further discussion of the role of deposit other than the observation that plaintiff, by depositing copies prior to initiating suit, complied with the 1793 law.

21. Judgment of 29 therm. an 12, Cass. crim., [1791] 1 Dev. \& Car. 1.1023, Veuve Malassis c. Busseuil (works by clerics; bishops held to own copyrights like other citizens; rationale: "the more publicly useful the work and the more it is related to public instruction, the more necessary it is to eliminate counterfeit editions that are not avowed by their authors").

22. Judgment of 5 brum. an 13, Cass. crim., [1808] 2 Dev. \& Car. 1.12, 4 J. Pal. 220, Letourmy c. Huet-Perdoux concerned a design for wallpaper, comprised of designs taken from prior sources; plaintiff argued that the combination of the two prior designs yielded a work "entirely new." He also suggested, "The point is not to determine whether the design copied by [defendant] is my own property. But it is certain that I was the first to deposit it at the Bibliotheque nationale." 4 J. Pal. at 220. The court held protection to be reserved to "those who truly are authors, those to whom belongs the first conception of a work." 2 Dev. \& Car. at 12-13. Since plaintiff's design was copied from prior sources, he had no claim.

23. Judgment of 6 niv. an 13, Cass. crim., [1808] 2 Dev. \& Car. 1.48, Williams c. Collignon (undisclosed literary work; issue concerned calculus of damages).

24. Judgment of 17 niv. an 13, [1808] 2 Dev. \& Car. 1.53, 4 J. Pal. 329, Pleyel c. Siebert (foreign musical work; no protection in France for works by foreigners published abroad; suggestion that unauthorized copies of new works made in France after foreigner's acquisition of French citizenship might be actionable. 
In his plaidoirie, plaintiff's lawyer seemed to have assumed that fulfillment of formalities was an element of acquisition of the property right: "Once the deposit is made, the author is master of his works; no one may publish or sell them without his permission; his works are from that point an inviolate property." 4 J. Pal. at 329. Plaintiff's advocate also, unsuccessfully, essayed some moral-rights-sounding arguments against defendant's rearrangement of Pleyel's works for different instruments. Id. at 329-30.)

25. Judgment of 5 flor. an 13, Cass. crim., [1808] 2 Dev. \& Car. 1.103, Buisson c. Joly (French translation of Adam Smith's Wealth of Nations and work titled Le Souper de Vaucluse; issue concerned regularity of seizure).

26. Judgment of 16 brum. an 14, Cass. crim., [1808] 2 Dev. \& Car. 1.177, Bruisset c. Guichard (work of religious devotionsame work as in 19; author assigned the work prior to 1793; heirs held to have no rights under 1793 law because author had already granted his rights pursuant to prior law).

27. Judgment of 29 frim. an 14, Cass. crim., [1808] 2 Dev. \& Car. 1.197, Vahlen c. Guillaume (subject matter: dramatic works of Florian, translation of Cervantes's Don-Quichotte and the history Numa Pompilius; liability found for unauthorized copies made in Belgium pre-unification, but sold post-unification; calculus of damages for infringing sales).

28. Judgment of Oct. 23, 1806, Cass. crim., [1808] 2 Dev. \& Car. 1.299, Bruysset c. Albert Joly (Italian grammar; basic work long in public domain; court ruled that plaintiff's additions were too insignificant to revive protection in work. Court also stated that under the 1793 law it was "formal and clear" that "the author of a work acquires the public property right in it by conforming to formalities." Id. at 300.)

29. Judgment of July 2, 1807, Cass. crim., [1808] 2 Dev. \& Car. 1.406, Clémendot c. Giguet et Michand (poem and essay, $L$ 'Imagination by Delille; issue: elements of criminal infringement).

30. Judgment of Dec. 2, 1808, Cass. crim., [1808] 2 Dev. \& Car. 1.609, Guillaume c. Stapleaux (works of Florian, including Estelle and Galatée, Don-Quichotte (translation from Cervantes), and Le Théâtre; infringing sales not presumed from listing of work in defendant's catalogue).

31. Judgment of Dec. 2, 1808, Cass. crim., [1808] 2 Dev. \& Car. 1.609, Bernardin de St.-Pierre c. Stapleaux (studies of 
nature; infringing sales not presumed from listing of work in catalogue).

32. Judgment of Mar. 23, 1810, Cass. crim., [1809-11] 3 Dev. \& Car. 1.167, Sieber c. Erard (musical work; French grantee first publishing in France and effecting dépôt légal entitled to bring infringement action in France).

33. Judgment of July 3, 1812, Cass. crim., [1812-14] 4 Dev. \& Car. 1.143, 143 n.5, Dentu c. Malte-Brun (geographies; issue appears to concern quantum of copying; distinction made by advocates between infringement and plagiarism: copying without attribution of unprotectable material-geographical commonplaces-and even of scattered portions of new material, may be plagiarism; it is not infringement because, according to the Avocat général, there was no harm to author's property right, but merely to his fame [limited concept of substantial copying entailing infringement]).

34. Judgment of July 3, 1812, Michaud c. Prud'homme, cited in Judgment of July 3, 1812, $1812 \mathrm{~J}$. Pal. at n. 536 (holding in the same terms).

35. Judgment of Sept. 4, 1812, Cass. crim., [1812-14] 4 Dev. \& Car. 1.185, Dentu c. Guillaume (translations of Ossianic and other bardic poetry; issue concerned calculus of damages).

36. Judgment of Nov. 17, 1814, Cass. crim., [1812-14] 4 Dev. \& Car. 1.630, Robin c. Romagnesi (sculpture held within subject matter protected by 1793 law "toute autre production des beaux arts"; no deposit required).

37. Judgment of Dec. 2, 1814, Cass. crim., [1812-14] 4 Dev. \& 1.636 , Leclerc c. Villeprend et Brunet (protectability of compilations; originality of arrangement of old works of religious instruction).

See also:

1. Précis pour Edme Bidault librairie à Dijon, pour servir à sa requette présentée à la Cour de cassation and summary of Judgment of 9 mess. an 13, noted supra at App. 15.1.

2. Mémoire pour Antoine Pilardeau imprimeur de Paris contre $M$. Bel capitaine de gendarmerie à Avignon (1806). This work contains lawyers' memoranda concerning piracy actions by Paris publisher Pilardeau against provincial unauthorized publishers/ sellers of a work variously titled Les Galanteries de Faublas, Oeuvres du Chevalier de Faublas, L'Ami des Dames de Faublas. 
One defense, apparently unsuccessful, asserted that the work was too licentious to deserve copyright protection.

The case between Pilardeau and Capitaine Bel is not in fact an infringement claim, but one for false imprisonment. It seems that rather than executing a seizure of a local pirate's edition, the Avignon constable (allegedly in complicity with the pirate) locked up the Paris publisher instead. 